\title{
The Holy Maid of Wales: Visions, Imposture and Catholicism in Elizabethan Britain
}

\author{
Alexandra Walsham (University of Cambridge)
}

\begin{abstract}
:
This article explores the case of Elizabeth Orton of Overton in Flintshire, a young girl who experienced two ecstatic visions in February and March 1581 and was later exposed as a fraud. First, it uses this intriguing incident to illuminate the precarious stability of the Elizabethan polity at a moment of acute political crisis, when the fate of the Reformation itself seemed to be balanced on a knife edge. It contends that religious developments in north Wales and the Marches were far more significant than has previously been recognised and investigates how far it was inflected by Welsh patriotism. Secondly, it focuses attention on the rhetorical strategies by which Elizabeth Orton was discredited - on the modes of argument that were utilised in the ensuing contest about her own authenticity and about the truth of the Catholic religion. Setting aside the question of whether or not she was guilty of faking her trances and revelations, it suggests that the incident sheds fresh light on the nature and evolution of the entangled concepts of the imposture, hypocrisy and fraud. It shows how anxiety about the status and source of Elizabeth's ecstatic experiences converged with intense concern about a second species of deceit and dissimulation: religious conformity.
\end{abstract}


At 8pm on the feast of Candlemas 1581 a thirteen-year-old girl from Overton in Flintshire who was sitting by the fireside in her father's house suddenly began to weep. ${ }^{1}$ She fell down on her knees in front of her stepmother, sobbing and sighing that her time was appointed, and begging the forgiveness of any that she had offended. 'Wateryng her praiers with salte teares', she declared herself a 'sinfull wretche' and cried 'fy fy on this wretched worlde'. Shortly thereafter she fell into an ecstasy, during which her eyes grew 'bigger then Hailestones' and she was 'pitifully troubled with intollerable paines', worse than the travails of a woman in childbirth. She begged the Virgin Mary to forgive her the temporal punishments due to her sins 'with very devoute gestures and blubbered cheekes'. But her request was not granted and she was thrust into Purgatory, a hideous place resembling a large furnace full of pitch, resin, grease, brimstone and boiling lead, and punished 'from the breast dounewarde'. She foamed at the mouth, cried pitifully, and appeared to be consumed by a 'cruell burnynge heate'. In the midst of her 'unspeakable tormentes', she praised the Lord and called upon his holy name, her words 'such as became the servant of God'. Eyewitnesses wondered how her 'yong and tender fleshe could endure the same' and despaired of her life, but 'their wittes were ... ravished to behold suche a lamentable sight'. She slept briefly and uneasily before losing all of her senses and appearing to lie 'starke dead'. When she awoke, she complained 'that all the joyntes of her bodie were so weary, as if they had been stretched out of the Racke'. When she was examined regarding her experiences the following day, she told how an angel had appeared to her in the guise of 'a goodlie faire birde' with the body of sparhawk, the face of a man, and the beak of a pigeon, who led her to Jesus and his mother.

\footnotetext{
* This essay has had a prolonged gestation. Versions of it have been presented in Cambridge, London, Maynooth, Melbourne, New Orleans, Oxford, and Tübingen and it has benefited from comments made on each of those occasions. I am also grateful to the following for reading drafts and offering advice: Lloyd Bowen, Anne Dillon, Michael Hunter, Peter Marshall, John Morrill, Adam Morton, Jinty Nelson, Katharine Olson, Lyndal Roper, and Lucy Underwood. It was completed during the tenure of a Leverhulme Major Research Fellowship and I am indebted to the Trust for its support.

${ }^{1}$ In the sixteenth century, it was known as Orton Madog, Orton Maddocke, or Overton. Throughout this essay it is referred to as Overton.
} 
Three weeks later, about seven o'clock at night on the feast of St Matthew the Apostle, Elizabeth had a second ecstatic experience. For two hours her body trembled, her veins pulsed, and she writhed in agony on her bed. This time she saw John the Baptist, Christ, the Virgin, St Anne, Mary Magdalene, the eleven apostles and was conveyed to a church splendidly furnished for the celebration of the holy Eucharist. In the midst of her fits Elizabeth also vociferously denounced 'the Religion of the Protestauntes' and 'their wicked and accursed Churche' as 'moste abhominable in Gods sight'. Her vehement diatribe against the established ecclesiastical order and its liturgical services 'wearied the eares' of at least some of her hearers. Declaring that she would never enter into a heretical church as long as she lived 'unlesse I be caried thether by force', she vowed to become a Catholic recusant. ${ }^{2}$

News of Elizabeth Orton's provocative visions soon spread in north Wales and the Marches. Based on her own testimony and that of eyewitnesses, a manuscript tract describing the events in Overton was soon circulating around the local Catholic underground. Multiple copies were allegedly sent to Ireland and some were said to have even reached France and Rome. ${ }^{3}$ Several fell into the hands of the Protestant authorities, who took decisive steps to attempt to suppress this subversive text and to apprehend the author and the seer herself. In early June 1581 the bishop of Chester, William Chaderton, sent the Privy Council two specimens of the tract about Elizabeth Orton's 'fained Visions', suspecting this to be 'the Invention of some Jesuite or other develishe Seducer'. It ordered him to interrogate the girl and, if she could not be induced 'to bewraye the same' by 'feare [fair] meanes', then she was

\footnotetext{
${ }^{2}$ Barnaby Rich, The true report of a late practise enterprised by a papist, with a yong maiden in Wales (London, 1582), sigs B1v-D4v, which is the verbatim transcription of 'The true report of two miracles or visions that appeared unto Elizabeth Orton ...' This Catholic manuscript tract, no copy of which appears to survive, explains that the visions occurred on 1 and 24 February 1580/1. The author first describes what the eyewitnesses observed and then Elizabeth Orton's own interpretation of her visions, 'as by diligent examination, I received it from out her own mouth' and 'as nere as my memorie can beare away'. Rich's pamphlet was entered in the Stationers Register on 23 April 1582: Edward Arber, ed., A Transcript of the Registers of the Company of Stationers of London, 1554-1640, A.D, 5 vols (London, 1875-1894), ii. 410.

${ }^{3}$ Rich, True report, sig. B1r.
} 
to be 'secretlye whipped, and so brought to declare the Truth of this Imposture'. ${ }^{4}$ Close questioning had no initial effect on Elizabeth, who 'still stoutly stoode to her tacklyng', but under duress she confessed that her ecstacies were a pretence, a confession she later denied and retracted. ${ }^{5}$ Transported to London and subjected to further questioning, she confirmed that she had been led astray by the 'wicked counsaile, and false practises, of that naughtie fellowe Hughes' - a 'vile runnagate papist' who had been her village schoolmaster and who had, she said, abused 'the simplicitie of my tender yeres'. ${ }^{6}$ On 4 March 1582, she was compelled to make a penitential confession regarding her role in counterfeiting her visions at Chester Cathedral and to hear a sermon denouncing her delivered by the dean, Christopher Goodman - the same Christopher Goodman who, during the reign of Queen Mary I, had written that most radical of work of Protestant resistance theory, How superior powers ought to be obeyed. ${ }^{7}$ He admonished those who witnessed her humiliation 'to beware of the subtill practices of Papistes, which were continually busied with seducing the simple and ignorant'. ${ }^{8}$ Elizabeth Orton's public exposure as a fraud soon became the subject of a scrurrilous pamphlet prepared by a professional soldier and semi-professional writer by the name of Barnaby Rich, which is the principal source for this compelling incident. En route back from a tour of duty in Ireland, where he had been involved in repressing the Desmond Rebellion,

\footnotetext{
${ }^{4}$ Chaderton's correspondence is printed in Francis Peck, Desiderata Curiosa: or, a Collection of Divers Scarce and Curious Pieces (Relating Chiefly to Matters of English History) in Six Books (London, 1732), bk 3, pp. 323, 34-5, 42-3. The Privy Council's letter is in Acts of the Privy Council, 1581-2, p. 98. John H. Langbein sets her punishment in the context of other warrants for torture: Torture and the Law of Proof: Europe and England in the Ancien Regime (Chicago and London, 2006 edn; first publ. 1976), pp. 106-7.

${ }^{5}$ Rich, True report, sig. B1r.

${ }^{6}$ Ibid., sigs A4r-v, A3v, A4r, quoting from the text of the confession she made at Chester.

7 Jane E. A. Dawson, 'Goodman, Christopher (1521/2-1603)', in Oxford Dictionary of National Biography [hereafter $O D N B$; all references are to the online edition, http://www.oxforddnb.com]. See also J. E. Bailey, 'Christopher Goodman, Archdeacon of Richmond, Rector of Aldford, a Native of Chester', Journal of the Chester and North Wales Architectural, Archaeological and Historic Society, NS, 1 (1887), pp. 138-57; Christopher Goodman, How superior powers oght to be obeyd of their subjects: and wherin they may lawfully by Gods worde be disobeyed and resisted (Geneva, 1558). Some of Goodman's correspondence from this period is held in the Denbighshire Record Office (Plas Power MSS DD/PP/839), though there are no references to this incident within these letters. I am grateful to Jane Dawson for sharing her transcriptions of this material.

${ }^{8}$ Rich, True report, sig. A3v.
} 
Rich had been present at the spectacle in the Cathedral. ${ }^{9}$ His pamphlet incorporated a verbatim transcription of the clandestine Catholic account, a copy of which had been given to him by Christopher Goodman, ${ }^{10}$ glossed with carping marginalia and topped and tailed by mocking commentary. Rich's pamphlet about the Orton affair is akin to a set of nested Chinese boxes. Deploying the polemical device of printing for refutation, ${ }^{11}$ it sought to discover the 'doltish devises' by which the Church of Rome perverted the English populace and to defuse the influence of a text that carried 'better credite' with Catholics in the Marches of Wales than 'either the Epistles of Sainct Paule, or the Gospelles of the fower Evangelistes'. Its aim was to unveil an act of deception perpetrated by a missionary priest and his young lay accomplice, a prophetess who he compared directly with Elizabeth Barton, 'the holie Maid of Kent', whose provocative revelations regarding Henry VIII's divorce became a cause célèbre and led to her execution in 1534. By perusing his account, Rich predicted, the 'reformed Protestaunte shall finde cause worthie to laughe at' and 'the wilfull Papyst matter to bee ashamed at'. ${ }^{12}$ The irony and paradox of Barnaby Rich's exposure of Elizabeth Orton's visions as a popish imposture is that in the process he provided them with the oxygen of publicity and preserved her remarkable story for posterity. We see her through a doubly distorting filter: through the lens of the unknown author of the illicit manuscript tract and through the spectacles of a satirical writer whose oeuvre defies neat categorisation and repeatedly breaks out of conventional generic boundaries. Depicting her as the puppet of male clerical conspirators, both serve to occlude her independence and agency. They also mediate and muffle her own words and voice.

\footnotetext{
${ }^{9}$ Ibid., sigs A3r-v, A4v-B1r. On Rich, see Willy Maley, 'Rich, Barnaby (1542-1617)', in ODNB; Thomas M. Cranfill and Dorothy Hart Bruce, Barnaby Rich: A Short Biography (Austin, TX, 1953).

${ }^{10}$ The dissemination of the Catholic pamphlet about Orton is reminiscent of the scribal circulation of accounts of the Maid of Kent: see Ethan Shagan, 'Print, Orality and Communications in the Maid of Kent Affair', Journal of Ecclesiastical History, 52 (2001), pp. 21-33.

${ }^{11}$ See Alexandra Walsham, 'The Spider and the Bee: The Perils of Printing for Refutation in Tudor England', in John N. King, ed., Tudor Books and Readers: Materiality and the Construction of Meaning (Cambridge, 2010), pp. 163-90.

${ }^{12}$ Rich, True report, sig. B1r, title-page.
} 
This article pursues two objectives in tandem and posits a link between them. First, it seeks to use this intriguing incident to illuminate the precarious stability of the Elizabethan polity at a moment of acute political crisis, when the fate of the Reformation itself seemed to be balanced on a knife edge. It contends that religious tensions and developments in north Wales and the Marches were far more significant than has hitherto been recognised. Arguing against a historiography that has dwelt on the triumph of Protestantism, it highlights the vigorous and militant drive for Catholic renewal in this region and investigates how far it was inflected by Welsh patriotism. ${ }^{13}$ Secondly, it focuses attention on the rhetorical strategies by which Elizabeth Orton was described and discredited - on the modes of argument that were utilised in the ensuing contest about her own authenticity and about the truth of the Catholic religion. ${ }^{14}$ Sidestepping the positivist question of whether or not she was guilty of faking her trances and revelations, it suggests that the incident nevertheless sheds fresh light on the nature and evolution of the entangled concepts of the imposture, hypocrisy and fraud. It explores how anxiety about the status and source of Elizabeth's ecstatic experiences converged with intense and growing concern about a second species of deceit and dissimulation: religious conformity.

\section{I: REFORMATION AND COUNTER-REFORMATION IN THE WELSH MARCHES}

Who was Elizabeth Orton? She was the daughter of John Orton, a gentleman retainer of Henry Stanley, the fourth earl of Derby, a leading landowner and key figure in the administration of the Welsh border region, who was lord lieutenant of Lancashire, commissioner for ecclesiastical causes, an active member of the Council of the North, and

\footnotetext{
${ }^{13}$ Especially as reflected in the work of Glanmor Williams, 'Wales and the Reformation', in Glanmor Williams, Welsh Reformation Essays (Cardiff, 1967) and Renewal and Reformation: Wales, c. 1415-1642 (Oxford, 1993 edn). See also Brendan Bradshaw, 'The English Reformation and Identity Formation in Wales and Ireland', in Brendan Bradshaw and Peter Roberts, eds., British Consciousness and Identity: The Making of Britain, 1533 1707 (Cambridge, 1998).

${ }^{14}$ This approach corresponds with that adopted by Jack Lynch in Deception and Detection in EighteenthCentury Britain (Farnham, 2008).
} 
later one of the queen's privy councillors. Her father was in the employment of a family that had abandoned its longstanding Yorkist allegiance to support the accession of the Lancastrian Henry Tudor in 1485 and which wielded immense political power in the region. He was a close associate of a man brought up in the court of Edward VI, whose commitment to Protestantism and determination to uphold the Elizabethan settlement contrasted with the devout Catholicism of his forebears. ${ }^{15}$ An English settlement in the division of Flintshire known as Maelor Saesneg which had been granted borough status by Edward I in 1292, Overton itself was a lordship of the Stanleys. ${ }^{16}$

The Ortons were an ancient landowning family of some stature and substance within this small town situated on an escarpment that winds its way around the course of the River Dee. ${ }^{17}$ John Orton seems to have married a well-heeled widow, Elizabeth verch Ieuan Lewes, a few years before Their home had a hall and a 'newe Parler' and they employed at least two serving maids. ${ }^{18}$ The list of witnesses to his daughter's visions appended to the manuscript tract attests to the family's connections of kin and friendship with important local worthies, including the earl of Derby's recorder, Thomas ap Jones Orton, two servants of Sir William Gerard, Lord Chancellor of Ireland and a member of the Council in the Marches, John

\footnotetext{
${ }^{15}$ Louis A. Knafla, 'Stanley, Henry, fourth earl of Derby (1531-1593)', in $O D N B$. On the family and its fortunes, see Barry Coward, The Stanleys: Lords Stanley and Earls of Derby 1385-1672, Chetham Society, $3^{\text {rd }}$ ser. 30 (Manchester, 1983). John Orton's status as his servant is noted on Rich, True report, sig. D1v. The parish register for Overton only survives from 1602.

${ }^{16}$ See George John Howson, Overton (Cauillid yn auncient tyme Orton Madoc) in Days Gone By (Oswestry, 1883), p. 57; Brian Done and Betty Williams, Overton in Times Past: A Brief History, ed. Jean Balderson and Martin Barnfather (Mold, 1992). It was a settlement of no more than 20 houses when John Leland visited it in the 1530s: The Itinerary of John Leland in or about the Years 1535-1543, 5 vols, ed. Lucy Toulmin Smith (London, 1964), iii. 67.

${ }^{17}$ A number of indentures and bonds relating to the Orton (or Overton) family survive in the National Library of Wales in Aberystwyth [hereafter NLW]. See NLW, Elwes 269 (bond of 1579); Elwes 290 (quitclaim of lands in Overton, 1584); Elwes 287 (lease of two farms of pastures by Henry, earl of Derby, to John Overton and Thomas his son, 1584); Elwes 289 (quitclaim of lands, 1584); Elwes 291 (quitclaim of lands in Overton, 1584); Elwes 32A (lease of three parcels of land by Henry, earl of Derby, and Thomas Orton, 1591); Elwes 631 (declaration of the uses of a fine levied in the court of Great Sessions, 1 June 1630, relating to lands of the late Thomas Orton); Elwes 655 (pre-nuptial agreement between Mary Orton and Edward Philips, 1 September 1631); C.1424-7 (willof Joan Overton, widow, 1624). These reveal that by the seventeenth century the Orton family owned many properties and hundreds of acres of land.

${ }^{18}$ See NLW, Elwes 266 (Bond of 1578, to abide by an award dated 25 September 1576 between 'Elizabeth verch Ieuan Lewes then wedowe and nowe wife to the said John Overton' and David Price).
} 
Edwards and John Humfey, and John Merick, the local minister. ${ }^{19}$ Elizabeth's grandmother appears to have been a member of the Conway family of Bodryddan, Rhuddlan, in

Denbighshire, which forged marriage alliances with the Welsh gentry in the fifteenth century, became prominent patrons of the bardic poets, and was tinged with Catholicism. Several of its members appear in presentments for recusancy in the Eizabethan and Jacobean period. ${ }^{20}$ Twenty-two miles from Chester and Shrewsbury, the world from which she emerged was thus a linguistic and cultural as well as an administrative frontier. Her acquaintances and relatives were members of educated, literate and bilingual elite which mediated between the organs of central government and monarchical authority and the largely monoglot population over which they had political and pastoral jurisdiction in this traditional rural society. ${ }^{21}$ The Protestantism of at least some of them may have been nominal. Overton became one of the many places in north Wales in which Catholics worshipped in secret: at Althey Hall just a few miles away in Bangor-on-Dee, a fine painted chapel and priest hole were installed in the late Elizabethan period. ${ }^{22}$ It is possible that John Orton himself was a church papist, a man whose prudent and politique outward compliance disguised an inward adherence to the old religion. By extension, it must also have been a source of embarrassment to her father's noble patron.

\footnotetext{
${ }^{19}$ Rich, True report, sig. D4v for the list of witnesses. Merick was vicar of Bangor Monachorum with Overton from 1565-92: Clergy of the Church of England Database (http://theclergydatabase.org.uk/; accessed 10 November 2015): CCEd Record ID 56641.

${ }^{20}$ Her grandmother is identified as Mistress Conway in Rich, True report, sig. C4r. For the Conway family, see Glanmor Williams, Recovery, Reorientation and Reformation: Wales c. 1415-1642 (Oxford, 1987), pp. 94, 99; E. Gwynne Jones, 'Catholic Recusancy in the Counties of Denbigh, Flint and Montgomery, 1581-1625', Transactions of the Honourable Society of Cymmrodorion (1945), pp. 114-33, at 121-2, 129.

${ }^{21}$ Lloyd Bowen, 'Information, Language and Political Culture in Early Modern Wales', Past and Present, 228 (2015), pp. 125-58. See also Richard Suggett and Eryn White, 'Language, Literacy and Aspects of Identity in Early Modern Wales', in Adam Fox and Daniel Woolf, eds, The Spoken Word: Oral Culture in Britain, 15001850 (Manchester, 2002), pp. 52-83; Helen Fulton, 'The Outside Within: Medieval Chester and North Wales as a Social Space', in Catherine A. M. Clarke, ed., Mapping the Medieval City: Space, Place and Identity in Chester c.1200-1600 (Cardiff, 2011), pp. 149-68, esp. 152-3.

${ }^{22}$ M. Bevan-Evans and W. Hugh Jones, Farmhouses and Cottages: An Introduction to Vernacular Architecture in Flintshire (Harwarden, 1964), p. 10; Done and Williams, Overton in Times Past, pp. 14-15; Kathryn Davies, Artisan Art: Vernacular Wall Paintings in the Welsh Marches, 1550-1650 (Little Logaston, 2008), pp. 193-4. For presentments for recusancy in Overton, see NLW, Great Sessions, 4/970/5/19 and 4/970/6/5; Jones, 'Catholic Recusancy', p. 133.
} 
Prior to her ecstasies in the winter of 1581 his daughter Elizabeth appears to have been a conforming Protestant. Born after the accession of the Protestant queen, she had been brought up on the Book of Common Prayer and the services of the established Church - or, in the words of the author of the Catholic manuscript tract, 'according to the corruption of the tyme, in ignorance and libertie'. ${ }^{23}$ Her first vision precipitated a kind of conversion experience, as a result of which she turned away from her former sinful life, forgoing '[out]ragious othes, idle talke, with other pleasures of the worlde', though she continued to use the English primer and 'refreined not the Service now used in Churches'. The second compelled her to repudiate the reformed faith in which she had been baptised and to reconcile herself with the proscribed Church of Rome. Though she was initially 'very loath' to do so because of 'the daungers and troubles that might insue', the memory of her vicarious trial in the fire of purgatory helped to convince Elizabeth that only by embracing Catholicism could she hope to find salvation. ${ }^{24}$ Her decision to defy the law regarding attendance at church must have seriously jeopardised the integrity of her household, placed it under unwelcome scrutiny, and raised grave questions about its political reliability. ${ }^{25}$

Her conversion was also a major coup for the seminary priests trained at Douai who were active in North Wales from the late 1570s: Overton was within the orbit of the shrine of the Celtic virgin martyr St Winifred at Holywell, the sacred spring that remained a focal point for conservative resistance and nocturnal journeys to hear mass throughout the later sixteenth and seventeenth centuries and which rapidly established itself as the headquarters of the

\footnotetext{
${ }^{23}$ Rich, True report, sig. B2r.

${ }^{24}$ Ibid., sigs C2v, D1r, D2v-3r. For a discussion of Elizabeth Orton's visions as a manifestation of youthful resistance, see Lucy Underwood, 'Recusancy and the Rising Generation', Recusant History, 31 (2013), pp. 51133, at 519-25; Lucy Underwood, Childhood, Youth, and Religious Dissent in post-Reformation England (Basingstoke, 2014), pp. 151-5.

${ }^{25}$ It evidently did not tarnish her father's standing with Henry Stanley. He leased him land in 1584 'for and in respect of the good lyking and opinion he conceyveth of the saide John Overton his servaunt': NLW, Elwes 287.
} 
seminary-trained missionaries operating in Flintshire during this decade. ${ }^{26}$ Among their number was one Edward Hughes, ordained at Cambrai in 1578, who was reported to be celebrating the Eucharist secretly in various houses and performing illicit baptisms in Denbighshire the following year. ${ }^{27}$ One of those present at these clandestine masses was the schoolmaster of Overton, Richard White (born Gwyn), whose contact with the Counter Reformation clergy seems to have cemented his commitment to the Church of Rome and induced him to move from refraining from Protestant communion to outright recusancy. ${ }^{28}$ Persuaded to comply by a local magistrate by the name of Roger Puleston 'against his stomacke', he interpreted a frightening attack by a company of kites and crows on his way home, during which he feared for his life, as a heavenly sign. ${ }^{29}$ This proved a decisive turning point and Gwyn's defiant nonconformity thereafter led to his ejection from his post, though he continued to teach in an old barn at Erbistock. Apprehended in Wrexham in 1580 by David Edwards, 'a hotte puritan' mercer full of 'spitefull hatred' to the Catholic religion, he proved to be an unruly and uncooperative prisoner. Carried from the gaol in his leg irons to be force-fed a Protestant sermon, he made such a noise rattling them that the preacher's voice could not be heard. Said to have described the established Church as domum diaboli, written

\footnotetext{
${ }^{26}$ Alexandra Walsham, 'Holywell: Contesting Sacred Space in Post-Reformation Wales', in Will Coster and Andrew Spicer, eds, Sacred Space in Early Modern Europe (Cambridge University Press, 2005), pp. 209-36. See also Glanmor Williams, 'St Winifred's Well: Ffynnon Wenfrewi', Flintshire Historical Society Publications, 36 (2003), 32-51. For Catholicism in north Wales, see Jones, 'Catholic Recusancy'; Martin Cleary, 'The Catholic Resistance in Wales 1568-1678', New Blackfriars, 38 (1957), pp. 111-25. Our knowledge of the religious history of this region will be transformed by a monograph by Katharine Olson, Pathways to Salvation: Popular Religion, Culture and Reformation in Wales and the Marches, c. 1400-1603 (Oxford, forthcoming).

${ }^{27}$ On Hughes, see D. Aneurin Thomas, ed., The Welsh Elizabethan Catholic Martyrs: The Trial Documents of Saint Richard Gwyn and of the Venerable William Davies (Cardiff, 1971), pp. 41-2, and ch. 3 passim; J.M.Cleary, 'Edward Hughes: A Seminary Priest in Maelor Saesneg, 1578-1595', Journal of Wrexham Local History Class: Bulletin of Local Studies, 1 (1962).

${ }^{28}$ See Daniel Huws, 'Gwyn, Richard [St Richard Gwyn] (c.1537-1584)', in ODNB. For White's presence at Hughes' mass, see Thomas, ed., Welsh Elizabethan Catholic Martyrs, p. 253, and see ch. 4.This volume contains editions of the two main sources for White's life, a contemporary MS, which was originally housed in the Mission House at Holywell, which may be the work of the Jesuit John Bennett; and the extract on White in John Bridgewater, ed., Concertatio Ecclesiae Catholicae in Anglia adversus Calvinopapistas et puritanos sub Elizabetha Regina (Trier, 1588). White's wife Catherine was a native of Overton.

${ }^{29}$ Thomas, ed., Welsh Elizabethan Catholic Martyrs, p. 87. White later tried to persuade Puleston to abstain from attending church and to acknowledge the Pope's authority: p. 95.
} 
rhymes against married ministers, and called 'the Bible a bubble', he was evidently an energetic and zealous proselytiser. Charged with the treasonous crime of attempting to reconcile people to the Catholic faith and papal allegiance, he was tortured, convicted and executed in October 1584, making him the proto-martyr of Wales. Reports of the 'manifest great and stranger wonders' worked by 'his blood, bones, ashes, \& other holy monuments' attest to the rapidity with which he acquired a cult as an incipient saint. ${ }^{30}$ This was the man responsible for instructing the youth of Overton and Elizabeth Orton was one of his pupils.

White's intense convictions found expression in the series of belligerent antiProtestant carolau he composed for singing in Welsh. One of these mocked the Reformation itself, poking fun at heretics who filled their paunch on Fridays, denied the oblation of Christ, opposed wax lights, burnt images, pulled down churches, denounced the saints and allowed the tinker, pedlar, cobbler, shoemaker and weaver to chatter the word of God; another told the story of the fatal Oxford assizes of 1577, when the persecuting judge who presided over the trial of the Catholic bookseller Rowland Jenkes died during an outbreak of gaol fever, together with other court officials. White is also credited with writing an insolent funeral ode or cywydd celebrating the assassination of the Dutch ruler William of Orange in 1584, which included ad hominem attacks on John Jewel, John Foxe, William Fulke, and the Welshman Gabriel Goodman, dean of Westminster, one of his persecutors. While this latter attribution is sometimes disputed, the vicious tone of the others was sufficient to hasten White's path to the gallows. ${ }^{31}$ Surviving in no less than a dozen manuscripts, White's carols provide evidence of a Catholic subculture that was sustained by networks of verbal exchange and manuscript circulation, as well as by printed texts such as the exile Morys Clynnog's Welsh language

\footnotetext{
${ }^{30}$ Ibid., pp. 88, 91, 95, 105, 130.

31 'The Carols of Richard White', in J. H. Pollen, ed., Unpublished Documents Relating to the English Martyrs, Catholic Record Society 5 (London, 1908), pp. 90-99. See also T. H. Parry-Williams, ed., Carolau Richard White (Cardiff, 1931). On the bardic culture in this region, see Enid Roberts, 'The Renaissance in the Vale of Clwyd', Flintshire Historical Society, 15 (1954-5), pp. 52-63.
} 
catechism, Athravaeth Gristnagoul, published with a preface by his colleague in Rome.

Gruffydd Robert. in $1568 .^{32}$ They utilised the vernacular as a supple and flexible medium for articulating and encoding dissident ideas. A hagiographical account of White's heroic life and death was also disseminated scribally, together with tales of the divine punishments suffered by the judge at his trial and the chief witness for the prosecution. ${ }^{33}$ These too were embellished as they were transmitted, attesting to the creative role of speech and rumour in forging an ethnically inflected sense of collective religious identity in defiance of the Protestant state. ${ }^{34}$ Offering an oblique and confused view of the religious milieu in which Elizabeth Orton grew up, Barnaby Rich's pamphlet appears to conflate Hughes and White into a single 'craftie and subtill seducer'. 35

In her vision, Elizabeth Orton was exhorted by John the Baptist to follow the counsel of a priest recently denounced as a 'seditious person' in the adjoining parish. ${ }^{36}$ This may have been Hughes, but an alternative possibility is John Bennett, a native of Flintshire and graduate of Douai who reached north Wales in May 1580 and was active in the area until his arrest two years later. After his deportation, he rejoined the mission and entered the Society of Jesus. According to his hagiographer, he travelled mostly on foot 'with exceeding zeale \& labour confirming such as he found sound in true ffaith, and reconciling other that were fallen

\footnotetext{
${ }^{32}$ Morys Clynnog, Athravaeth Gristnogaul, le cair uedi cynnuys yn grynno'r hol brifbynciau syd I gyfaruydo dyna $r$ y phord I baraduys ([Milan], 1568). See also Paul Bryant-Quinn, “"To Preserve our Language": Gruffydd Robert and Morys Clynnog', Journal of Welsh Religious History, 8 (2000), pp. 16-34. A brief answer to this 'short trifling treatise ... late set forth in the Britaine Tongue ... and lately spread secretly abroad in Wales' was published by Lewis Evans in 1571, but no copy appears to survive.

${ }^{33}$ Bowen, 'Information, Language and Political Culture', pp. 150-1. For the life, see Thomas, ed., Welsh Elizabethan Catholic Martyrs, pp. 85-131. No copy of a recorded print edition of the carolau of 1600 is now extant.

${ }^{34}$ See Alison Shell, Oral Culture and Catholicism in Early Modern England (Cambridge, 2007); Anne Dillon, The Construction of Martyrdom in the English Catholic Community, 1535-1603 (Aldershot, 2002), ch. 2.

${ }^{35}$ Rich, True report, sig. A4v. Thomas, ed., Welsh Elizabethan Catholic Martyrs, p. 43. It is not entirely impossible that Sir Hughes, who neither Elizabeth nor Rich identify explicitly as a priest was John Hughes (or John ap Hugh ap Madoc), a known recusant in whose home mass was said and who allegedly said that the 'churches of Protestants were ... full of wicked spirits' and that the Pope was supreme head of the Church. He was tried alongside Richard White as a proselytiser and convicted of felony and treason but reprieved: ibid., pp. 105-6, 110-11, 253.

${ }^{36}$ Rich, True report, sig. D3v.
} 
from it'. It is conceivable that he was the author of the Catholic manuscript tract about the 'merveilous Visions' revealed by the Lord in the village of Overton, which was written for the benefit of devout readers 'to the increase of his honour, confusion of his enemies, and comforte of his poore afflicted servaunts'. ${ }^{37}$ Another credible candidate is the Caernarvonshire-born missionary Robert Gwyn, a convert from Protestantism who returned to Wales from Douai in 1576 to work in the region, and so inspired his female followers that they fiercely rebuffed the 'heresiarch and pseudo-bishop' of Bangor, Nicholas Robinson, when he came to apprehend him. The author of Y drych Krisnogawl (which was partly printed in a coastal cave near Llandudno in 1586-7), most of his works were published scribally, including Gwyssanaeth y Gwŷr Newydd, a blunt and uncompromising exhortation against attendance at heretical services written around 1580. This is the Welsh counterpart of the Jesuit Robert Persons' Brief discours contayning certayne reasons why Catholiques refuse to goe to church (or 'Reasons of Refusal'), Gwyn's text took advantage of his distant geographical location and the inaccessibility of the language in which it was written to denounce Protestants as 'Gwyr Newydd a Loygr' (English novationes). In short, repudiating attempts to appropriate early British history to provide a precedent for the Reformation and reasserting Wales status as a seat of the ancient Catholic faith, he presented the new religion as a perverse foreign import. It is a measure of Gwyn's pre-eminence in this district that he was granted the power to consecrate portable altars and that he attended the conference of clergy at Uxbridge in October 1580, at which the Edmund Campion and Persons were also present. $^{38}$

\footnotetext{
${ }^{37}$ See Thomas M. McCoog, 'Bennett, John (c.1550-1625)', in ODNB; Thomas, ed., Welsh Elizabethan Catholic Martyrs, pp. 44-5, 317-21, at 318. The evidence for his possible authorship is circumstantial, but it has been argued that Bennett was responsible for the MS life of Richard White: ibid., pp. 140-1. Rich says that he publishes the tract 'as it was first penned by that great Clarke Johannes sive nomine': True report, sig. B1r. ${ }^{38}$ Thompson Cooper, 'Gwyn, Robert (c.1540-1604?)', rev. Ceri Sullivan, in ODNB; Thomas, ed., Welsh Elizabethan Catholic Martyrs, pp. 39-41; Gwssanaeth y Gwŷr Newydd: Robert Gwyn 1580, ed. Geraint Bowen (Cardiff, 1970). For a comparison between Gwyn's and Persons' arguments, see James January-McCann, 'Robert Gwyn and Robert Persons: Welsh and English Perspectives on Attendance at Anglican Service',
} 
The arrival of Persons and Campion in England in June 1580 is a critical context for understanding Elizabeth Orton's ecstasies. After the stir caused by his bold challenge to the Tudor establishment (his 'brag'), Campion retreated to Lancashire and while there wrote his famous Rationes Decem. His presence in the diocese of Chester was a source of concern to Henry Hastings, earl of Huntingdon, who wrote to the bishop that he was sure that Campion had been 'in divers Places, or I am wronge enformed' ${ }^{39}$ Meanwhile Persons masterminded the printing of his Brief discours, written under the pseudonym John Howlet and dedicated to Elizabeth I herself, to whom he appealed for toleration. ${ }^{40}$ The content of Elizabeth Orton's visions clearly reveals the imprint of both Gwyn's and Persons' books condemning conformity and defending recusancy as an act of conscientious objection. Evidence that the latter had quickly reached north Wales is testified by the fact that Richard White summarised the nine main arguments of the 'fluent bard' John Howlet in one of his carolau. This was another sharply edged attack on 'the church of Calvin' that said that the English Bible was 'topsy turvy' and warned that church papists were 'Servants of the Devil' and worse than Pagans, Turks and Jews. ${ }^{41}$ It is at least possible that the poem played a part in shaping Elizabeth Orton's emphatic rejection of religious conformity during her second ecstasy.

Tellingly, there was a conspicuous epidemic of recusancy in the small village of Overton in the months after the visions: alongside a number of married women, a certificate of names dating April 1581 records the sisters Ales and Lowry Lloyd and the brothers

\footnotetext{
Recusant History, 32 (2014), 159-71, esp. 169. On Catholic efforts to reclaim the British past, see Lloyd Bowen, 'The Battle of Britain: History and Reformation in Early Modern Wales', in Tadhg Ó hAnnracháin and Robert Armstrong, eds, Christianities in the Early Modern Celtic World (Basingstoke, 2014), pp. 135-50, at 144-7. ${ }^{39}$ Peck, Desiderata Curiosa, p. 36. For a definitive treatment of this period of Campion's life, see Gerard Kilroy, Edmund Campion: A Scholarly Life (Farnham, 2015), esp. pp. 186-211.

${ }^{40}$ John Howlet [Robert Persons], A brief discours contayning certayne reasons why Catholiques refuse to goe to church (Douai [East Ham], 1580). See Peter Lake and Michael Questier, 'Puritans, Papists, and the "Public Sphere" in Early Modern England: The Edmund Campion Affair in Context', Journal of Modern History, 72 (2000), pp. 587-627. On this tract in the context of the wider campaign for recusancy, see Alexandra Walsham, Church Papists: Catholicism, Conformity and Confessional Polemic in Early Modern England (Woodbridge, revised edn 1999; first publ. 1993), ch. 2.

${ }^{41}$ Pollen, ed., Unpublished Manuscripts, pp. 93-5.
} 
Thomas and Edward ap John Griffiths, though they were 'spared owte of thinditement' because of their youth. Under the age of sixteen, these children and adolescents must have been Elizabeth Orton's schoolmates. Their acts of resistance index the profound impact of her ecstasies in this small and close knit community of which she was part. ${ }^{42}$ Occurring in the interim between its appearance and Campion's arrest in July and execution in December 1581, Elizabeth's revelations reflected and fed the sense of hope and excitement about the future that spread in Catholic circles at this pivotal juncture. In letters written to the Pope and Father General of the Jesuit order in Rome around the same time, Persons boasted about the 'dauntless spirit' of the persecuted laypeople who courageously professed their faith before official tribunals, declaring that this change had been 'brought about by the right hand of God on high' and that it alarmed the heretics 'more than the armies of any Catholic princes' ${ }^{43}$

The incident also followed in the wake of momentous developments in Ireland, news of which readily filtered into Welsh border region from across the sea: the papally financed and Spanish-backed invasion led by James Fitzmaurice, accompanied by the Catholic priest and controversialist Nicholas Sanders. Conceived of as a crusade against the heretical queen Elizabeth, this came to grief with the massacre of Italian and Spanish troops at Smerwick in November 1580, but it added to an atmosphere in which further international intervention to effect regime change was widely expected. ${ }^{44}$ Plans for a Catholic assault on the British Isles, via the northern kingdom of Scotland, were also being fomented in France and English

\footnotetext{
${ }^{42}$ NLW, Great Sessions (Flintshire Gaol Files), 4/970/5/19 (Certificate of recusants, April 1581). Six months later several of these recusants had fallen away, though Ellyn, wife of Edward Lloyd, and Ales Lloyd, his servant (and possibly a relative) were listed among them. NLW, Great Sessions 4/970/6/5 (Certificate of recusants, September 1581). By the 1630s, the Ortons and Lloyds appear to have intermarried: see NLW, Elwes 631.

${ }^{43}$ Letters and Memorials of Father Robert Persons, S.J., ed. L. Hicks, Catholic Record Society 39 (London, 1942), p. 87 (Persons to Agazarri, August 1581).

${ }^{44}$ See G. A. Hayes-McCoy, 'The Completion of the Tudor Conquest and the Advance of the CounterReformation, 1571-1603', in T. W. Moody, F. X. Martin, and F. J. Byrne, eds, A New History of Ireland, vol. III, Early Modern Ireland 1534-1691 (Oxford, 1976), pp. 103-6; Steven G. Ellis, Ireland in the Age of the Tudors (London, 1998), pp. 311-15. Soldiers were sent to Chester to be ready for transportation to Ireland to suppress the rebellion in March 1580: John Harland, ed., The Lancashire Lieutenancy under the Tudors and Stuarts, 2 vols, Chetham Society 49-50 (1859), ii. 111-19.
} 
Catholic exiles in Paris linked with the duke of Guise eagerly expected intervention from this direction: in April 1580 their co-religionists in Rome wrote to bolster their morale, saying 'the heretics of England will not be suffered to continue long in their mischievous proceedings' ${ }^{45}$ If copies of the manuscript account of Elizabeth Orton's visions did reach France, they can only have helped to encourage the hope that the Church of Rome would soon be restored to dominance once more.

Destabilising rumours and prophecies that threatened Protestant rule were circulating in Wales too. It may be significant that discontent with the current regime and wishful thinking about an alternative claimant to the throne sometimes crystallised around the Stanleys themselves, as descendants of Henry VIII's youngest sister, Mary Brandon. A Montgomeryshire widow brought before the Court of Great Sessions in 1590 for claiming that 'a certein noble man of the Realme' who she named as 'Lord Strange' would reign after the queen's death was by no means alone in pinning her hopes on the heir to a dynasty which had long been the focus of Galfridian prophecy and mythology. ${ }^{46}$ Immediately following the death of the fourth earl in September 1593 Richard Hesketh was sent to try to persuade Ferdinando to assert his hereditary right to the crown, usurp Elizabeth, and rule as a Catholic king, though this spectacularly backfired when the fifth earl turned him over as a traitor instead. A significant figure in this scheme was Sir William Strange, who in 1587, following an illustrious military career in Ireland and the Low Countries, defected to Spain and spent the rest of his life petitioning Philip II to invade England via the Isle of Anglesey. Some suspected that Ferdinando's sudden death the following year was the result of poisoning in revenge for his non-cooperation in these wild Catholic schemes. But this gesture of loyalty

\footnotetext{
${ }^{45}$ Katy Gibbons, English Catholic Exiles in Late Sixteenth-Century Paris (Woodbridge, 2011), pp. 51-3. Welsh Catholics were members of the community in Paris: see CSP Foreign 1579-80, p. 250.

${ }^{46}$ NLW, Great Sessions (Montgomery Gaol Files) 4/134/2/89. Ferdinando had the courtesy title Lord Strange. For the Galfridian tradition surrounding the family, see Aisling Byrne and Victoria Flood, 'The Romance of the Stanleys: Regional and National Imaginings in the Percy Folio', Viator, 46 (2015), pp. 327-52.
} 
did not entirely dispel the penumbra of distrust that hovered around this noble family, in which Robert Persons and other Jesuits displayed considerable interest as potential leaders of a rebellion. ${ }^{47}$ Although these events occurred a decade after Elizabeth Orton's visions, but they are indicative of the highly charged environment from which they emerged. They underline the point that Wales was no sleepy backwater remote from the international politics of the European Counter Reformation; riddled with latent conservative sentiment and overt Catholic allegiance it was a gateway through which a violent reconversion of the queen's realms with the aid of foreign power might have been successfully launched. Indeed, the invasion scheme outlined in the memorandum written by Morys Clynnog to Cardinale Morone and Pope Gregory XIII in 1575 identified Chester as the best landing place for an expeditionary force that would overthrow the regime of a queen whom he hated as 'that woman who has usurped the kingdom of England' and whom he believed had been deprived of her right to rule by the bull Regnans in Excelsis. ${ }^{48}$

\section{II: MYSTICS, VISIONS AND MIRACLES}

It is against this backdrop that we must read the manuscript tract about the episode in Overton that travelled from Flintshire to the continent the following year, which bears witness to the process by which the subjective experiences of an impressionable young girl were edited by its author to endorse the spiritual priorities of the missionary clergy. Upholding doctrinal beliefs and liturgical practices at the heart of the ideological battles being waged between Catholics and Protestants during this period, Elizabeth's memory of her visions was evidently

\footnotetext{
${ }^{47}$ See Coward, The Stanleys, pp. 145-6; J. J. Bagley, The Earls of Derby, 1485-1985 (London, 1985), pp. 64-67; David Kathman, 'Stanley, Ferdinando, fifth earl of Derby (1559?-1594)', in ODNB; Rory Rapple, 'Stanley, Sir William (1548-1630)', in $O D N B$. The Hesketh plot is recorded in a contemporary urban chronicle: Chester, Cheshire Archives and Local Studies Service, DCC 11 (Cowper Manuscripts), fo. 73r. See also Victor Houliston, 'Filling in the Blanks: Catholic Hopes for the English Succession', Sederi, 25 (2015), pp. 77-104, at $87-8$.

${ }^{48}$ See J. M. Cleary, 'Dr Morys Clynnog's Invasion Projects of 1575-6', Recusant History, 8 (1966), pp. 300-22, at 311-12; Bryant-Quinn, "'To Preserve our Language”, 22; Geraint Bowen, 'Morys Clynnog (1521-1580/1)', Transactions of the Caernarfonshire Historical Society, 27 (1966), pp. 73-97, at 92.
} 
moulded by the people by whom she was questioned, in an almost catechetical fashion, after the event. They buttressed the sacramental mystery of the mass and thereby the contested doctrine of transubstantiation. The ceremony Elizabeth described was celebrated by John the Baptist dressed in white vestments with a cross on his breast and back and it was accompanied by a sermon in Latin. When examined 'more perticulerly' about the liturgical details of the rite she had witnessed, it proved to be 'in all poinctes agreable to ... the Romaine use restored by the counsaile of Trent, and preached by the Seminarie [priests] in England' ${ }^{49}$ If her graphic account of the terrors of purgatory bears some of the hallmarks of medieval devotional literature ${ }^{50}$ it also strongly affirmed a theological tenet which Protestants dismissed as a belatedly invented popish tradition, and which likewise became a litmus test of Catholic commitment, confirmed by a conciliar decree in $1563 .^{51}$ Elizabeth's communication with the departed souls of a young girl called Alice Jova and of her grandmother Mistress Conway proved that there was no irrevocable rupture between the realms of the living and the dead. ${ }^{52}$ Her visions likewise sanctioned the use of sacramentals: the apparition of John the Baptist commended the use of rosary beads as 'of singular vertue to praie withall'. But the Catholic writer was more ambivalent about her call for a copy of St John's gospel to be hung around her neck - this was a traditional prophylactic amulet that perhaps smacked a little too much of superstition and magic. Although he insisted that this practice had the sanction of 'the famous Jesuit Father Robertes', he could not disguise his discomfort about the fact that the talisman had been supplied to her by the local Church of England minister rather than a lawful priest, referring this to the 'secret dispensation' of God,

\footnotetext{
${ }^{49}$ Rich, True report, sigs D3v-4r.

${ }^{50}$ As remarked by Underwood, 'Recusancy and the Rising Generation', 520.

${ }^{51}$ H. J. Schroeder, ed., Canons and Decrees of the Council of Trent (Rockford, IL, 1978 edn), p. 214. The Douai professor of divinity Richard Bristow published a defence of William Allen's book on this topic the same year as her appearance as a seer: A reply to Fulke, in defense of $M$. D. Allens scroll of articles, and booke of purgatorie (Louvain [East Ham], 1580). See Peter Marshall, Beliefs and the Dead in Reformation England (Oxford, 2002), p. 134.

${ }^{52}$ Rich, True report, sig. C4r.
} 
who had used the timeserving vicar (whom Elizabeth believed to be 'in hart a Catholike'), to 'beare witnesse to the truthe against him self and his owne profession' ${ }^{53}$ While some aspects of the episode proved harder to assimilate into the framework of the reformed Catholicism imported by the missionaries than others, their value as propaganda for Tridentine Catholicism was undoubtedly enhanced as they were related and then translated onto to paper for wider dissemination.

At the same time, Elizabeth Orton's raptures bear witness to both the resilience and subtle transmutation of older devotional patterns. They must be situated in the context of a vibrant Welsh brand of feminine sanctity that had deep roots, not least in the guise of veneration of virgin martyrs such as St Winifred, whose nearby shrine she may well have visited. ${ }^{54}$ They also reflect a long line of 'secretaries of God' - pious people, often women, who claimed to have had direct encounters with the divine and to be the special envoys of messages from heaven, prominent among which was Julian of Norwich. By the late Middle Ages this native tradition was being inflected by the rise of the new mystical spiritualities associated with Catherine of Siena, Bridget of Sweden, and Henry Suso in the Rhineland, which left their mark on the religious outlook of leading laity as well as the cloistered religious. ${ }^{55}$ This included Lady Margaret Beaufort, patron of the Bridgettines at Syon Abbey, translator of the fourth book of Thomas Kempis's Imitation of Christ, and the dedicatee of Walter Hilton's Scale of Perfection, who married (for the fourth time) Thomas Stanley, first earl of Derby in 1472, and may have been responsible for restoring the well and chapel at the

\footnotetext{
${ }^{53}$ Ibid., sigs D3r, C4r-v. 'Father Robertes' may refer to Robert Persons or possibly Robert Bellarmine. For this practice, see Keith Thomas, Religion and the Decline of Magic (Harmondsworth, 1973 edn), pp. 34, 60, 221, 328-9; Eamon Duffy, The Stripping of the Altars: Traditional Religion in England 1400-1580 (New Haven and London, 1992), p. 216. For the halting progress of the Reformation in Wales, see Katharine K. Olsen, "'Slow and Cold in the True Service of God": Popular Beliefs and Practices, Conformity and Reformation in Wales, c.1530-c.1600', in Ó hAnnracháin and Armstrong, eds, Christianities, pp. 92-107.

${ }^{54}$ Jane Cartwright, Feminine Sanctity and Spirituality in Medieval Wales (Cardiff, 2008), esp. ch. 2.

${ }^{55}$ See Diane Watt, Secretaries of God: Women Prophets in Late Medieval and Early Modern England (Woodbridge, 1997); Nancy Bradley Warren, The Embodied Word: Female Spiritualities, Contested Orthodoxies, and English Religious Cultures, 1350-1700 (Notre Dame, IN, 2010), which emphasises continuities across the medieval-early modern divide.
} 
at the thaumaturgic spring at Holywell. ${ }^{56}$ Wales was not untouched by the winds of change that were invigorating orthodox Catholic piety in the pre-Reformation period.

The mode of religious introspection that became increasingly popular among cloistered religious and devout laypeople in the late fifteenth and early sixteenth century was not without dangers and vulnerabilities. Learned churchmen such as Jean Gerson and Pierre D'Ailly became increasingly preoccupied with the thorny question of 'discernment of spirits' - with the problem of differentiating divine inspiration from demonic delusion and physical and psychological illness. Doubt and scepticism about such phenomena was instrinsically related to belief in them. It intensified in the context of growing philosophical anxieties that were destabilising the boundaries between the natural, preternatural and supernatural, as a number of historians have shown. ${ }^{57}$ Their effect was to surround visions and other sensory perceptions of God, the saints and the afterlife with an aura of suspicion, even as they simultaneously placed a premium on empirical experience as a means of authenticating them. Visionaries and their clerical confessors worried that their ecstatic feelings might be temptations placed by Satan in the path of their salvation and that the heavenly visitors they received awake and sleeping were in fact fiends. ${ }^{58}$ In pre-Reformation England much uncertainty initially surrounded the disturbing symptoms and clairvoyant gifts exhibited by the twelve-year-old maid of Ipswich, Anne [or Jane] Wentworth, whose dramatic convulsions were temporarily relieved after a vision of the Virgin and finally cured following a visit to a nearby chapel of Our Lady in 1515. Only gradually did witnesses to her fits overcome their

\footnotetext{
${ }^{56}$ See Michael K. Jones and Malcolm G. Underwood, 'Beaufort, Margaret, countess of Richmond and Derby (1443-1509)', in $O D N B$. I have also benefited from hearing an unpublished paper by Virginia Bainbridge, 'Lady Margaret Beaufort, St Winifred's Well and the Welsh Bridgettines'.

${ }^{57}$ Dyan Elliott, 'Seeing Double: Jean Gerson, the Discernment of Spirits, and Joan of Arc', American Historical Review, 107 (2002), 26-54; Nancy Caciola, Discerning Spirits: Divine and Demonic Possession in the Middle Ages (Ithaca, NY, 2003), ch. 6; Nancy Cacioloa and Moshe Sluhovsky, 'Spiritual Physiologies: The Discernment of Spirits in Medieval and Early Modern Europe', Preternature: Critical and Historical Studies on the Preternatural, 1 (2012), pp. 1-48.

${ }^{58}$ See Gwenfair Walters Adams, Visions in Late Medieval England: Lay Spirituality and Sacred Glimpses of the Hidden Worlds of Faith (Leiden, 2007), pp. 177-89.
} 
incredulity. This 'great miracle' was endorsed by the humanist Thomas More in his Dialogue against heresies, but he was scandalised by the case of the maid of Leominster, a 'straunge wenche' who 'lyved withoute any mete or drynke' and claimed to be fed with 'aungels fode'. When the pieces of consecrated host flew through the air from the altar to the rood were revealed to be an elaborate hoax perpetrated by the girl and her lover, the prior, the pair were made to perform public penance for abusing the faith of innocent pilgrims. ${ }^{59}$ Anticipating the episode in Overton half a century later, incidents such as these troubled the devout and temporarily tainted the reputation of the late medieval Church.

These dilemmas became more acute against the backdrop of the theological controversies precipitated by Europe's parallel Reformations. In sixteenth- and seventeenthcentury Europe, the Inquisition and other tribunals subjected many 'aspiring saints' in Italy, Spain, and France to searching scrutiny: some, including the Carmelite nun Teresa of Avila, eventually received official imprimatur and were canonised, but many others were dismissed as victims of disease; dupes of Satan; or ventriloquists' dolls manipulated by male clerical confederates, who were themselves agents of that arch-magician and father of lies. Accused of 'feigning their revelations' and 'inventing the sacred', it became common to brand such men and women with the labels imposter and hypocrite. ${ }^{60}$ Claims to be able to see, hear and touch transcendental beings were embroiled in debates about the contested status of truth in a world that seemed to be beset by illusion.

\footnotetext{
${ }^{59}$ Richard Rex, 'Wentworth, Jane [ the Maid of Ipswich] (c.1503-1572?)', in ODNB; Thomas More, A Dialogue Concerning Heresies, in The Complete Works of St Thomas More, vol. 6, pt 1, ed. Thomas M.C. Lawler et al (New Haven, 1981), pp. 93-4, 87-8 respectively.

${ }^{60}$ See Anne Jacobsen Schutte, Aspiring Saints: Pretense of Holiness, Inquisition, and Gender in the Republic of Venice, 1618-1750 (Baltimore, 2001); Stephen Haliczer, Between Exaltation and Infamy: Female Mystics in The Golden Age of Spain (Oxford, 2002); Andrew Keitt, Inventing the Sacred: Imposture, Inquisition, and the Boundaries of the Supernatural in Golden Age Spain (Leiden, 2005); Stuart Clark, Vanities of the Eye: Vision in Early Modern European Culture (Oxford, 2007), ch. 6; Moshe Sluhovsky, Believe not Every Spirit: Possession, Mysticism and Discernment in Early Modern Catholicism (Chicago, 2007), esp. ch. 7; Susan E. Schreiner, Are You Alone Wise? The Search for Certainty in the Early Modern Era (Oxford, 2011), ch. 6; Clare Copeland and Jan Machielsen, eds., Angels of Light? Sanctity and Discernment of Spirits in the Early Modern Period (Leiden, 2013).
} 
The pattern of sickness combined with prophetic percipience at the heart of Elizabeth Orton's visions thus reflected a strand of spirituality which had been enlivened as well as problematised by the onset of the Protestant and Catholic movements for religious renewal. Like other mystical women, her ecstasies attest to a highly affective and sensory strain of piety which manifested itself in voluminous weeping and intense anguish. She too had a gift of seeing the divine inwardly that led her to eschew material aids to devotion and faith: though she received 'with very great reverence' a small crucifix given to her by one company that assembled around her, she nevertheless commented 'what need I ... to have the Picture of Christe, when I see hym present before myne eyes' ${ }^{61}$

Intent upon offsetting suggestions that her symptoms emanated from epilepsy or mental instability, the author of the Catholic manuscript tract was at pains to stress that she had 'the perfecte use of her witte and memorie'. Yet Elizabeth herself was evidently worried that her senses might be deceiving her: she feared that the 'heavenly quire' of apostles and saints that appeared before her might be 'wicked Sprites or Goblines'. As for the figure of Christ, this was no ghost, without flesh or bones, but a real being that could be handled and felt. ${ }^{62}$ She shared the deep-seated concern about the source of her otherworldly experiences that doomed so many early modern seers to obscurity, if not condemnation and discipline. No less strikingly, when certain gentlemen who had heard reports of the maiden's ecstasies came to examine her in April 1581 and found that she had forgotten everything, one of the company ('suspecting the malice of the ghostly enemie') caused her to make the sign of the cross on her forehead and breast, 'whereupon incontinently' she 'uttered more then she could

\footnotetext{
${ }^{61}$ Rich, True report, sig. D1r.

${ }^{62}$ Ibid., sig. B3r, D2v. For the very similar sensory experiences of the English Carmelite nuns in Antwerp and Lierre, see Nicky Hallett, The Senses in Religious Communities, 1600-1800: Early Modern 'Convents of Pleasure' (Farnham, 2013).
} 
remember at any tume before'. In this instance, educated contemporaries came to believe that the devil had conspired not to create, but to suppress her extraordinary revelations. ${ }^{63}$

It may well be asked why Elizabeth Orton's clerical associates did not diagnose her disturbances and revelations as the work of Satan and his human accomplices. Her story bears some remarkable resemblances to that of the French demoniac Nicole Orby, whose celebrated exorcisms at Verviens and Laon in 1566, allegedly witnessed by 150,000 people, became a highly charged baroque spectacle, the central figure in which was the possessing devil Beelzebub, who revealed himself to be an arch-Huguenot. His explusion through the agency of the Holy Eucharist, functioned as powerful propaganda for the Real presence as well as a potent metaphor of the explusion of heresy from France as a whole. ${ }^{64}$ The failure of Elizabeth Orton's clerical associates to follow in the footsteps of their French colleagues is intriguing, especially in view of the later, more famous cases of the children and adolescents dispossessed by the Jesuit William Weston at Denham in 1586-7, whose behaviour was similar and whose exorcisms were likewise celebrated in a manuscript tract as proof that Rome was the true Church. ${ }^{65}$ Her divine ecstasies exemplified a brand of charismatic spirituality that fostered ambivalence and conflict within Catholic ranks, but in this instance its potential disadvantages appear to have been outweighed by its benefits to a church under the cross. The circumstances of persecution that pertained in England and Wales made the threat which possession and prophecy presented to clerical authority and the ecclesiastical hierarchy seem less dangerous than they did in France. ${ }^{66}$ The discourse of moderate scepticism about the supernatural that Francis Young has detected swirling beneath the

\footnotetext{
${ }^{63}$ Rich, True report, sig. D4v.

${ }^{64}$ D. P. Walker, Unclean Spirits: Possession and Exorcism in France and England in the Late Sixteenth and Early Seventeenth Centuries (London, 1981), pp. 19-28; Sarah Ferber, Demonic Possession and Exorcism in Early Modern France (London, 2004), ch. 2. Obry too began as a visionary, and it was only later that the clergy diagnosed her disturbance as the work of the devil rather than a divine messenger.

${ }^{65}$ See Francis Young, 'Catholic Exorcism in Early Modern England: Polemic, Propaganda and Folklore', Recusant History, 29 (2009), pp. 487-507; Francis Young, English Catholics and the Supernatural, 1553-1829 (Farnham, 2013), ch. 6. See also Ferber, Demonic Possession, ch. 1.

${ }^{66}$ On this issue, see also David Harley, 'Explaining Salem: Calvinist Psychology and the Diagnosis of Possession', American Historical Review, 101 (1996), pp. 307-330.
} 
surface of English Catholic piety throughout this period, precipitating division between clergy and laity, Jesuits and seculars, did not inhibit her identification as a true seer. ${ }^{67}$

Indeed, the straitened situation in which Catholics in the British Isles found themselves predisposed them to believe that God would send miracles to confirm their beleaguered religion. ${ }^{68}$ The event also occurred in a climate of apocalyptic anxiety and a mood of millenarian anticipation, which the arrival of the Jesuits in June 1580 served to intensify. Reflecting an atmosphere of anticipation akin to that which Denis Crouzet has detected in France and which Geoffrey Parker has discerned behind the 'messianic vision' of Philip II of Spain, ${ }^{69}$ the appearance of Campion and Persons was perceived by some as a fulfilment of Joachite prophesies. This found expression in heightened sensitivity to the significance of portents and signs - monstrous births, apparitions of spectral ships, castles and fighting armies in the sky, and the eerie sound of baying hounds, as well as the 'great earthquake' (or rather minor tremor) that shook London and the southeast in April 1580 and the blazing star or meteor seen in October of the year. ${ }^{70}$ To some Catholics at least these prefigured an imminent showdown between the forces of light and darkness and a dramatic turnaround of the fortunes of the Church of Rome. And it is clear from reports of a mysterious apparition of three men dressed in 'dazzling white robes' and a flock of ethereal sheep observed by men cutting and mowing hay in a field near Overton that these mingled hopes and fears were shared by people living in the vicinity of the village in which Elizabeth

\footnotetext{
${ }^{67}$ Young, English Catholics and the Supernatural, p. 21, ch. 1 and passim.

${ }^{68}$ Alexandra Walsham, 'Miracles and Counter Reformation Mission to England', Historical Journal, 46 (2003), pp. 779-815, esp. 812 .

${ }^{69}$ Denis Crouzet, Les guerriers de Dieu: la violence au temps des troubles de religion (vers 1525 - vers 1610) (Champ Vallon, 1990); Geoffrey Parker, 'The Place of Tudor England in the Messianic Vision of Philip II of Spain', TRHS, 6th ser., 12 (2002), pp. 167-221. See also Jennifer Spinks, 'Print and Polemic in SixteenthCentury France: The Histoires Prodigieuses, Confessional Identity, and the Wars of Religion', Renaissance Studies, 27 (2011), pp. 73-96.

${ }^{70}$ Robert Persons noted that the 'vulgar sort' of people were 'much moved' by the arrival of the Jesuits in the wake of 'strange signs and wonders that fell out at that time': see 'Of the Life and Martyrdom of Father Edmund Campion', Letters and Notices, 57 (1877), pp. 219-42; 58 (1877), pp. 308-39; 59 (1878), pp. 1-68, at 22-7. See also Alexandra Walsham, "This Newe Army of Satan": The Jesuit Mission and the Formation of Public Opinion in Elizabethan England', in David Lemmings and Claire Walker, eds., Moral Panics, the Media and the Law in Early Modern England (Basingstoke, 2009), pp. 41-62.
} 
Orton grew up. Retrospectively read as a harbinger of the martyrdom of the schoolmaster Richard White, who himself was heard to affirm that the world 'would not last long', the incident opens a window into the mentality of Welsh Catholics at this time. ${ }^{71}$ It helps to explain why the marvellous visions vouchsafed to the daughter of John Orton were read as forerunners of the impending 'confusion of [God's] enemies' and 'comfort of his poore afflicted servaunts'. ${ }^{72}$ Their potency as weapons with which to defend the Catholic cause and to precipitate conversions lay in the fact that Protestants were no less finely attuned than their confessional adversaries to the workings of divine providence in the temporal world.

It may also owe something to the bardic tradition of which her schoolmaster Richard White was a custodian and transmitter: a tradition which fostered the view that early modern Welshmen had no less vital a part to play in the rejuvenation of the Catholic faith than the Celtic saints who had first planted Christianity in these islands. The fame of his death 'pierced the hearts of all Wales from north to south' who honoured 'his patience and constancy for the faith of the old Britons their dear progenitors'. He was directly compared with 'his blessed countryman' St Alban, the nation's first Christian missionary martyr, and said to have retraced his 'happy steps'. ${ }^{73}$ In the mid 1570 s, Morys Clynnog described the prophetic 'songs and rhymes ... repeated in the mouths of all, in their own native tongue' which predicted their liberation and compared the prospects for a Roman Catholic restoration in Wales with the ancient Israelites awaiting the advent of the Messiah. In a climate of patriotic zeal and pride about the Welsh as the loyal bearers and heirs of the ancient Christianity professed by the British people, it is perhaps not surprising that deep-seated misgivings of about female ecstatic experiences were eclipsed by the conviction that Elizabeth Orton had been selected as an instrument of the Almighty to restore the land to the

\footnotetext{
${ }^{71}$ Thomas, ed., Welsh Elizabethan Catholic Martyrs, pp. 249-51, 105 respectively.

${ }^{72}$ Rich, True report, sig. B2r.

${ }^{73}$ Thomas, ed., Welsh Elizabethan Catholic Martyrs, p. 126. See Jason Nice, Sacred History and National Identity: Comparisons between Early Modern Wales and Brittany (London, 2009), esp. ch. 4.
} 
faith of its forefathers. ${ }^{74}$ Briskly dismissing the scepticism of 'incredulous person[s]', the author of the manuscript tract hailed Elizabeth as a kind of virgin martyr herself: invoking the text of Wisdom 3, 'In a Furnace our Lorde hat received his chosen, and as a burnt offeryng he hath accepted them for ever', he implicitly compared her vicarious sufferings in purgatory with the heroic sacrifices in defence of the old religion being made by a new generation of saints. $^{75}$

\section{III: PROTESTANTISM AND THE PROBLEM OF PROPHECY}

However, publicising miracles of this kind always had the capacity to backfire badly. They carried the risk of handing fresh ammunition to Protestant propagandists intent upon proving that Catholicism was rooted in Antichristian delusion and reliant upon legerdemain to secure allegiance to it. The epistemological instability of visions made this a strategy that could expose the Church of Rome to damaging allegations of imposture that might seriously stain its moral and ideological integrity, as well as place a stumbling block in the path of weak believers. It is perhaps in this context that we should interpret the immediate response of the relatives and friends who were privy to Elizabeth's first vision, which was 'to treade underfoote the miracle'. ${ }^{76}$ Her ecstasies could all too easily be invoked by reformed writers as evidence of the inherent duplicity of the Catholic religion and to confirm the resilient stereotype of the innocent young woman perverted by the popish priesthood.

This was a strand of thought with roots in the medieval past which, as Peter Marshall has shown, was reanimated and injected with fresh urgency in Henrician England. Humanist criticism of embarrassing abuses and 'superstitions' fused with eschatological expectation of the end of the world to accentuate attention to religious counterfeiting. It provoked an

\footnotetext{
${ }^{74}$ See Cleary, 'Dr Morys Clynnog's Invasion Projects', pp. 306-7; Bowen, 'Morys Clynnog (1521-1580/1)', p. 92.

${ }^{75}$ Rich, True report, sig. C2v.

${ }^{76}$ Ibid., sigs C2v-3r.
} 
obsession with the forged and fabricated wonders wrought by Antichrist and with the false prophets that Scripture warned would proliferate in the last days that contributed to the 'perplexing fragility' exhibited by some aspects of traditional religion in the early years of the English Reformation. ${ }^{77}$ It was a language that had broad polemical utility and resonance in this society: Simon Fish spoke of the 'cloked ypocrisi' of the mendicant friars in his Supplication for Beggars of 1529 and in a sermon of 1527 Hugh Latimer denounced the 'great imposture' perpetrated by popish priests, whom it became commonplace to depict visually as wolves disguised in sheep's clothing and to accuse of creating pious frauds to pull the wool over the eyes of the illiterate. ${ }^{78}$ According to the reformers, the ultimate con-trick was the Eucharist itself and they mercilessly mocked the miracle of transubstantiation at the heart of the mass as a mummery. The effect of such polemic was to cement the idea that Catholicism had a 'pathological predisposition to deceit and lying' and to entrench it permanently in Protestant culture and thinking. ${ }^{79}$

Nothing in the reign of Henry VIII did more to reinforce this evolving assumption than the case of Elizabeth Barton, the nun of Kent, whose seditious predictions of the king's death if he persisted in dissolving his marriage with Catherine of Aragon led swiftly to a show trial that resulted in her conviction as a traitor. Her feigned trances and 'devilish illusions' were denounced in sermons delivered in London and Canterbury in November and December 1533. The surviving text was a setpiece on the theme of popish forgery and laid much of the blame on her confessor Dr Edmund Bocking, who, it was said, had 'daily rehearsed matter enough unto her' out of the revelations of St Bridget of Sweden and St

\footnotetext{
${ }^{77}$ Peter Marshall, 'Forgery and Miracles in the Reign of Henry VIII', Past and Present, 178 (2003), pp. 39-73, at 40. See also Helen L. Parish, Monks, Miracles and Magic: Reformation Representations of the Medieval Church (Abingdon, 2005), esp. chs 3, 5, 6.

${ }^{78}$ Simon Fish, A supplicacyon for the beggars ([Antwerp?, 1529?]), fos 1v, 6v; Sermons by Hugh Latimer, Sometime Bishop of Worcester, Martyr, 1555, ed. George Elwes Corrie (Cambridge, 1844), p. 47.

${ }^{79}$ Marshall, 'Forgery and Miracles', 65.
} 
Catherine of Siena. ${ }^{80}$ The act of her attainder was similarly saturated with the vocabulary of hypocrisy, craft and dissimulation and chroniclers like Edward Hall spoke of her as a 'holy hypocrite' who had been persuaded by her clerical advisers to practise 'juggling and crafty deceit' - the same language that pervaded the indictment of Elizabeth Orton nearly fifty years later. ${ }^{81}$ It was also invoked when an eighteen-year-old Londoner called Elizabeth Croft confessed that 'moved by divers lewd persons' and induced by bribes, she had pretended to be the Holy Spirit in the form of a white bird that spoke from a wall in Aldersgate with the aid of a shistle. The public declaration she was compelled to make included a warning 'to beware of heresies', which her seditious words against Mary and Philip, as well as the mass and confession, were evidently designed to support. ${ }^{82}$ Her humiliation was no doubt a source of embarrassment to the Protestant cause and it probably served to reinforce not just the trope that the weaker sex were inherently prone to sin and temptation, but also the reformers' ingrained distrust of people who claimed to convey messages from heaven.

This is not to say that Protestantism was inherently opposed to the possibility that authentic seers might still appear. If Scripture taught that the devil often disguised himself as an angel of light, it also supplied support for the idea that the Lord sometimes commissioned humble and obscure individuals to convey heavenly messages to his people on earth, particularly when the Last Judgement loomed on the horizon. As it was written in Joel,

\footnotetext{
${ }^{80}$ See L. E. Whatmore, ed., 'The Sermon against the Holy Maid of Kent', English Historical Review, 58 (1943), 463-75. On the influence of these saints on Barton, see Diane Watt, 'The Prophet at Home: Elizabeth Barton and the Influence of Bridget of Sweden and Catherine of Siena', in Rosalynn Voaden, ed., Prophets Abroad: The Reception of Continental Holy Women in Late-Medieval England (Cambridge, 1996), pp. 161-76. See also Watt, Secretaries of God, ch. 3; 'Reconstructing the Word: The Political Prophecies of Elizabeth Barton (1506-1534)', Renaissance Quarterly, 50 (1997), 136-63. See also Sharon L. Jansen, Dangerous Talk and Strange Behaviour: Women and Popular Resistance to the Reforms of Henry VIII (Basingstoke, 1996), chs 3 and 4. In the light of the Orton case, it is difficult to endorse Gwenfair Walters Adams' suggestion that 'The hanging of Elizabeth Barton sounded the death knell of the late medieval English vision': Visions, p. 204. Barton retained a reputation for sanctity in recusant circles after her death: see Diane Watt, 'The Posthumous Reputation of the Holy Maid of Kent', Recusant History, 23 (1996), pp. 148-58.

${ }^{81} 25$ Henry VIII, c. 12; Edward Hall, The Triumphant Reign of Henry VIII, ed. Charles Whibley, 2 vols (London, 1904), ii. 244-5, 247-59.

${ }^{82}$ See John Stow, A summarie of the chronicles of England (London, 1598), p. 284; Raphael Holinshed et al, The first and second volumes of chronicles (London, 1587), vol. iii, pp. 1117-18; Charles Wriothesley, A Chronicle of England during the reigns of the Tudors, from A.D. 1485 to 1559, 2 vols, Camden Society, NS, 11, 20 (1875-77), ii. 117-18.
} 
chapter 2: 'your sons and daughters shall prophesy, your old men shall dream dreams, you young men shall see visions'. Reformed theologians generally stressed that prophesy had ceased in the post-apostolic era and that the Lord no longer fed his faithful with milk like babes. Prophecies and revelations were the swaddling bands and walking frames of the infant church. Like miracles they had become redundant and gradually faded away. Most individuals who claimed to have the gift of foreseeing the future or to have visited heaven or hell in their dreams were deemed to be victims of 'the subtill illusions of the Divell' or the cunning machinations and 'deceitfull legierdemaine' of monks and priests. ${ }^{83}$ But, like Catholics, Protestants could not completely rule out the possibility that God might raise a true prophet: this would be to 'binde or manacle the handes of him that made all the world' ${ }^{84}$ Peter Martyr Vermigli, for instance, acknowledged that the Almighty did sometimes appoint such extraordinary emissaries 'to restore things unto order'. ${ }^{85}$ In Lutheran Germany, this loophole provided scope for many humble laypeople to believe that they had been entrusted with the task of preaching repentance by angels dressed in white robes. Some of these apparitions often evoked suspicion but others were vindicated by the clergy convinced that times were so desperate that God was obliged to use tools other than the ordained ministry. ${ }^{86}$ In Calvinist England, just weeks before Elizabeth Orton experienced her visions, an elevenyear-old named William Withers of Walsham-le-Willows in Suffolk fell into a trance on Christmas Eve 1580, and awoke from it to deliver an excoriating denunciation of contemporary vice and to predict the devastating judgements that would befall the nation if it

\footnotetext{
${ }^{83}$ See John Harvey, A discoursive problem concerning prophesies, how far they are to be valued or credited (London, 1588), p. 50.

${ }^{84}$ The quotation is from Henry Howard, A defensative against the poyson of supposed prophesies (London, 1583), sig. A4r. See Alexandra Walsham, 'Frantick Hacket: Prophecy, Sorcery, Insanity and the Elizabethan Puritan Movement', Historical Journal, 41 (1998), pp. 27-66, at 43-51; Providence in Early Modern England (Oxford, 1999), pp. 203-18.

${ }^{85}$ Peter Martyr Vermigli, Common places, trans. A. Marten (London, [1583]), p. 24.

${ }^{86}$ Jurgen Beyer, 'A Lübeck Prophet in Local and Lutheran Context', in Bob Scribner and Trevor Johnson, eds., Popular Religion in Germany and Central Europe, 1400-1800 (Basingstoke, 1996), pp. 166-82. The story of a husbandman's daughter resurrected from the dead to prophesy in January 1580 became an international bestseller: Eyriak Schiltenberger, A prophecie uttered by the daughter of an honest countrey man, called Adam Krause (London, 1580).
} 
failed to repent of its iniquity. The boy was heralded by puritan preachers and laypeople as a 'second Daniel', sent to awaken the populace 'out of the perilous slumber of our sinne', since people paid so little heed to the teaching of the reformed clergy. The notion that innocent adolescents and children might function as prophets was thus not wholly inimical to Protestants. $^{87}$

Inevitably, though, the aggressively confessional content of Elizabeth's visions weighed heavily against accepting that she too was a genuine envoy. Together with her subordinate status as a woman and child, they led instead towards the suggestion that she was a demoniac, a counterfeit, or suffering from some form of disease or lunacy. Assessing the source of her false prophetic consciousness was no less fraught with difficulty on this side of the Reformation divide than it was within the Church of Rome. Categorising experiences of this kind involved a set of conscious and unconscious calculations about the best way of limiting the damage caused by such revelations: both inclined to the view that "nothing can bee more opposite to discretion then distemper, to prophecy then furye' and deplored the propensity of the vulgar to revere the pronouncements of 'raving Cassandras' and 'diseie Damsells' like the holy maid of Kent. ${ }^{88}$ An anonymous compiler of a town chronicle of latesixteenth century Shrewsbury, who may have the story from the mouths of traders and travellers passing through on their way from the Welsh Marches as well as read Rich's pamphlet, compared Elizabeth Orton's visions with 'a madd dreame' and suspected that she had been 'inchantid by soom connyng papist or dyvell to delude the people to supersticion agayne'. He thanked God that 'in the cleare light of the gospell' such cases of 'conjuringe or

\footnotetext{
${ }^{87}$ John Philips, The wonderfull worke of God shewed vpon a chylde whose name is William Withers, being in the towne of Walsam, within the countie of Suffolke (London, 1581), sigs A8r, B6v, and passim. On this case, see Alexandra Walsham, 'Out of the Mouths of Babes and Sucklings: Prophecy, Puritanism and Childhood in Elizabethan Suffolk', in Diana Wood, ed., The Church and Childhood, Studies in Church History 31 (Oxford: Blackwell for the Ecclesiastical History Society, 1994), pp. 285-99.

${ }^{88}$ Howard, Defensative, sig. K1v. It is possible that Howard's text, which vigorously defended his religious orthodoxy and seems to have been particularly directed at astrologers, was partly inspired by the Orton case the previous year.
} 
dyvylishe spekinge in any persoon tormentd' no longer perverted people from the true faith. ${ }^{89}$ But the official line was that the fifteen-year-old was not a victim of possession or witchcraft but rather a fraudulent imposter who, seduced by a priest, had knowingly deceived those around her into believing her 'unseene visions' ${ }^{90}$ And it was this theme that dominated the theatrical ritual of recantation she was made to perform in Chester on 4 March 1582.

\section{IV: THE POLITICS OF ANTI-CATHOLICISM AND THE APOCALYPSE}

To understand why this explanation for her ecstasies prevailed and why such decisive steps were taken to repress them we must return to the local and national context in which this incident occurred. The apprehension of Elizabeth Orton and the hunt for her accomplices coincided with a fierce drive against recusancy which had preoccupied William Chaderton since his elevation to the see of Chester in November 1579. Working in alliance with the earl of Derby, he engaged in an energetic campaign to purge the area of 'that dangerous Infection of Poperie' that earned him the praise and gratitude of William Cecil, Francis Walsingham, and Henry Hastings, President of the Council of the North. He was excused from attending Parliament in 1581 in order to continue his relentless efforts to track down 'lewd' and 'seditious' reconcilers, sayers and hearers of mass, roving priests and corrupt tutors and he was uncompromising and merciless when he discovered them. In May of that year he meted out 'verie sharp Correction' to an 'obstinate Papist' by the name of James Apsden, who had uttered 'blasphemous Speeches against God' and was notoriously disobedient to the Queen's laws. He is also known to have deployed the strategy of removing children from their parents for Protestant re-education. The Privy Council evidently had no need to remind Chaderton that if he was remiss and negligent in his role he would 'answere the same before Almightie God'. He was assiduous in seeking those who 'sowe[d] this wicked Seede of Poperie and

\footnotetext{
${ }^{89}$ Shrewsbury, Shrewsbury School, MS Mus X. 31 ('Dr Taylor's book'), fo. 139v.

${ }^{90}$ Rich, True report, sig. A4v.
} 
Disboedience' within his sphere of jurisdiction. ${ }^{91}$ The events in Overton probably explain why Welsh bishops received an urgent directive from London to take action against 'all schoolmasters, public and private'. ${ }^{92}$ They likewise illuminate the order issued to local churchwardens a few months later asking them to report 'Sedicious people calling their selves Jesuits' as well as those who kept 'books repugnant to the doctrine now allowed', impugned Protestant services 'eyther by proff[esies] or rymes', disturbed divine service and went to the wonder-working shrine at Holywell. ${ }^{93}$

This febrile atmosphere helps to account for the anxiety that Elizabeth Orton's visions engendered at the highest level, but so too does the fact that they occurred in a parish contiguous with estates owned by a prominent member of the queen's government, Thomas Egerton. Egerton had been brought up in the household of Thomas Ravenscroft of Bretton in Flintshire, and had close connections with Bishop Chaderton, Henry Stanley, fourth earl of Derby, and Robert Dudley, earl of Leicester. ${ }^{94}$ By 1581 he had laid aside his own youthful sympathies for the Catholic cause and become implacably opposed to 'the devilish doctrine of Rome', as well as heavily involved in the prosecution of recusants and Jesuits. Six years later he would play a critical part in the execution of Mary Queen of Scots. Appointed to the office of Solicitor General just as the investigation of this episode got underway, he evidently took the lead in interrogating the girl when she reached London. The appearance of a young Welsh prophetess virtually on his doorstep simply could not be ignored. ${ }^{95}$ It indicated and underlined the strength of sympathy for the Catholic cause in the Marcher region.

\footnotetext{
${ }^{91}$ Peck, Desiderata Curiosa, book 3, esp. pp. 16, 30, 31, 34-5, 41. See also Christopher Haigh, 'Chaderton, William (d. 1608)', in ODNB; K. R. Wark, Elizabethan Recusancy in Cheshire, Chetham Society, $3^{\text {rd }}$ ser. 19 (1971), esp. ch. 3. VCH Cheshire, ed. C. R. Elrington, vol. 3 (Oxford, 1980), p. 23. On the struggle to secure the Reformation, see Penry Williams, The Council of the Marches of Wales under Elizabeth I (Cardiff, 1958), ch. 4, esp. pp. 90-99; Williams, Recovery, Reorientation and Reformation, ch. 13; Glanmor Williams, Wales and the Reformation (Cardiff, 1997), ch. 10, esp. 268-9.

${ }_{92}$ See Acts of the Privy Council 1581-2, pp. 427-8.

${ }^{93}$ NLW, Great Sessions (Denbighshire Gaol Files), 4/6/2/24.

${ }^{94}$ On Leicester in this region, see Williams, Council of the Marches, p. 92.

${ }^{95}$ On Egerton, see J. H. Baker, 'Egerton, Thomas, first Viscount Brackley (1540-1617)', in ODNB.
} 
It is transparently clear that the Elizabethan authorities feared that the Elizabeth Orton affair had the potential to become a political scandal on the same scale as the nun of Kent. It happened at a moment of intense crisis for the regime: not merely in the wake of the Desmond rebellion and Fitzmaurice's thwarted invasion of the west coast of Ireland, but also amid the turmoil and controversy surrounding the revival of negotiations for a royal match between Elizabeth I and Francois de Valois, now duke of Anjou in 1579. This aroused immense anxiety in the ranks of forward Protestants at court and in the country as a whole, as John Stubbes' provocative Discovery of the Gaping Gulf revealed. ${ }^{96}$ Thomas McCoog has convincingly argued that the mission launched by Persons and Campion in June 1580 was conceived against this background as a strategic political intervention to prepare the way for a Catholic restoration. 1581 was consequently a highpoint of official concern about the domestic and international threat posed by a European Counter Reformation that appeared to be gathering momentum. ${ }^{97}$ The moral panic about the Jesuits that gripped Britain during these years also converged with growing concern about the cryptic sect of the Family of Love, who were regarded as another group of wolves in sheep's clothing: many mainstream Protestants saw Familists and Jesuits as two sides of the same diabolical coin. Both were the disciples of Satan and their simultaneous appearance was a sure sign that contemporaries were living in the last days of the world. ${ }^{98}$

Mirroring the mindset of their confessional enemies, some Protestants were reaching a pitch of fearful anticipation about the approaching apocalypse. This was given expression in various texts: Abraham Fleming's Bright Burning Beacon about the 1580 earthquake,

\footnotetext{
${ }^{96}$ John Stubbes, The discouerie of a gaping gulf vvhereinto England is like to be swallovved by another French mariage, if the Lord forbid not the banes, by letting her Maiestie see the sin and punishment thereof ([London], 1579).

${ }^{97}$ Thomas M. McCoog, 'The English Jesuit Mission and the French Match, 1579-1581', Catholic Historical Review, 87 (2001), pp. 185-213. See also John Bossy, 'English Catholics and the French Match', Recusant History, 87 (2001), pp. 185-213.

${ }^{98}$ See Christopher Marsh, The Family of Love in English Society, 1550-1630 (Cambridge, 1994), ch. 5; Christopher Carter, 'The Family of Love and its Enemies', Sixteenth Century Journal, 37 (2006), pp. 651-72; Walsham, "This Newe Army of Satan", p. 51.
} 
Thomas Rogers' The General Session (1581), and Stephen Batman's Doome Warning all Men to the Judgement, published just as news was breaking of Elizabeth Orton's visions. ${ }^{99}$ Infused with the view that history was hurtling towards an eschatological conclusion, Batman's book was an English version of Conrad Lycosthenes' Latin compendium of prodigies of 1557, augmented with recent examples. These included many of the omens and portents that we have seen were causing a stir in Catholic circles and a number of others, including a fire at Patrick Brumpton near Richmond in 1577 which he interpreted as a prelude to the destruction and massacre in the town of Naas in Co. Kildare by the 'Wilde Irishe'. He similarly saw the story of a plague of mice in the marshes of Dengie Hundred in Essex, which was devoured by an influx of owls at Allhallowtide 1580, as a forewarning of the arrival of 'some undermining and swift warlike people'. He implicitly connected this and other events with the 'great and assured hope' of the victory of 'the Popish religion that grew that year, inspired by the arrival of the Jesuit 'locustes' and the swarming abroad of 'the broode of the same crew'. Interpreted by some historians as a 'subtle sequel' to John Stubbs' inflammatory attack on the Anjou match in the Gaping gulf, the Doome reflected sentiments that were shared by many fervent Protestants in the circles of Sir Philip Sidney and the earl of Leicester, but also well beyond court. ${ }^{100}$ It was a text which gave expression to the view that the final curtain was nigh. Like the Shrewsbury chronicler, at least some saw the episode in

\footnotetext{
${ }^{99}$ Abraham Fleming, A bright burning beacon (London, 1580); Thomas Rogers, The general session (London, 1581); Stephen Batman, The doome warning all men to the judgemente (London, 1581). For the context, see Richard Bauckham, Tudor Apocalypse: Sixteenth-Century Apocalypticism, Millenarianism and the English Reformation from John Bale to John Foxe and Thomas Brightman (Abingdon, 1978), esp. chs 8-9.

${ }^{100}$ Batman, Doome, pp. 403-4, 386, 412. See John R. McNair's introduction to his facsimile edition (Delamar, NY, 1984), esp. p. viii. A marginal note in Batman's commonplace book draws the topic connection explicitly: 'be ware of French myce, and Spanish owles: Cambridge, MA, Harvard University Houghton Library MS Eng 1015, fo. 13r. Blair Worden, The Sound of Virtue: Philip Sidney's Arcadia and Elizabethan Politics (New Haven, 1996), ch. 6. A true report of the strange commynge and building of myse in the marshes of Dengie Hundred in Essex was entered in the Stationers' Register on 4 May 1581, but no copy is now extant. See Arber, ed., Transcript of the Registers, ii. 392.
} 
Overton as further evidence that 'the dyvyll in these dayes begin to r[i]se and stur hym self knowinge that the latter days ys at hande ...'. ${ }^{101}$

The sense of emergency provoked by the arrival of the Society of Jesus and the attempted invasion of Ireland manifested itself in royal proclamations ordering missionary priests to leave the country ${ }^{102}$ and a programme of parliamentary legislation that defined them as traitors and introduced crippling fines for refusing to attend public Protestant services and for hearing mass privately. Sir Walter Mildmay's impassioned speech to the House of Commons captured the mood: he spoke with transparent hatred of the 'rable of vagrant fryers newly sprung upp and coming through the world to trowble the Church of God', urged the creation of laws 'to provide for the more streight holding of them', and wished that 'they may withall taste of such punishment as is fit for such persons as withdrawe theire dew obedience from their soveraigne'. ${ }^{103}$

The passage of the savage anti-Catholic act of 1581 at almost exactly the same time as Elizabeth Orton's first ecstasy is surely more than a coincidence. ${ }^{104}$ The rapid rise of recusancy to which that statute was an urgent response was partly a product of the concerted drive against outward conformity by the Catholic missionary clergy and hierarchy embodied by Gwyn's Gwssanaeth y gwŷr newydd and Persons' Brief discours. As Peter Lake and Michael Questier have emphasised, the latter functioned as a provocative challenge to the legitimacy of the Tudor regime and its religious policy; as we have seen the former was even more hard edged in tone, calling the heretics bastardied (bastards), declaring that God's power was above that of any mortal monarch, and scathingly denying that the queen had any

\footnotetext{
${ }^{101}$ Shrewsbury School, MS Mus X. 31 ('Dr Taylor's book'), fo. 139v.

${ }^{102}$ See the proclamation of 10 January 1581: Paul L. Hughes and James F. Larkin, eds., Tudor Royal Proclamations, 3 vols (New Haven and London, 1964-9), ii. 481-4.

103 T. E. Hartley, ed., Proceedings in the Parliaments of Elizabeth I, 3 vols (Leicester, 1981-95), i. 504-5, 528.

${ }^{104}$ See ibid., i. 533-42.
} 
right to dictate her subject's behaviour in matters of religion. ${ }^{105}$ The timing of Elizabeth Orton's own pronouncements against church papistry made them too little short of a declaration of war, a defiant Welsh call to civil disobedience that the authorities instinctively situated on a spectrum at the extreme end of which stood treason. They encouraged an act of political resistance that ironically paralleled the doctrine that Christopher Goodman, a central figure in the investigation into the Orton affair, had delineated in his famous book of 1554 . In it he trenchantly justified placing allegiance to God above that which Protestants owed to ungodly magistrates and tyrannical rulers, with whose wicked commandments they could legitimately refuse to comply when they contradicted divine will and the dictates of their own consciences. ${ }^{106}$

Elizabeth's visions need to be relocated within a moment when Catholics daily expected that they would soon be engulfed in 'a new and bitter storm of persecution'. ${ }^{107}$ And some zealous Protestants thought that the laws passed by Parliament did not go far enough. Stephen Batman's book was itself an oblique intervention in the debate about how best to contain and eliminate the Catholic threat. He saw the birth of a double-headed child in Northumberland in 1579 as a warning to subjects 'for doubling with religion', to 'Officers for dissembling with the lawe and justice', and 'to Princes, that they beware while they professe the Gospell, they yet suffer false religion'. Buried in his catalogue of portents was the critical remark that England lacked a statute allowing the execution of papists for their religious convictions alone. How, he asked, could the Reformation and the commonwealth be secure without this? Until 'this be better reformed', Batman stressed, England and Wales could 'looke for no peaceable tranquillitie, but rather that it breede a grievous Tyrannie, from the

\footnotetext{
${ }^{105}$ Lake and Questier, 'Puritans, Papists, and the "Public Sphere" in Early Modern England'. For Gwyn's tract, see January-McCann, 'Robert Gwyn and Robert Persons', 164, 167, 168.

${ }^{106}$ Goodman, How superior powers oght to be obeyd. For a discussion of the interconnections between Catholic and Protestant resistance theories, see Stefania Tutino, 'Huguenots, Jesuits and Tyrants: Notes on the Vindiciae Contra Tyranos in Early Modern England', Journal of Early Modern History, 11(2007), pp. 175-96.

${ }^{107}$ Letters and Memorials, ed. Hicks, p. 66.
} 
which God defend thys oure Realme and Countrey'. ${ }^{108}$ Batman's comment reflects a current of discontent about the strategy of securing outward conformity that had been the cornerstone of the Elizabethan settlement in 1559 and which remained central to anti-Catholic legislation for the rest of her reign - a strategy which seemed to some to be a mandate for religious insincerity.

\section{V: DISSIMULATION, DECEIT, AND IMPOSTURE}

The episode in Overton thus occurred in the context of concern about another species of dissimulation - a concern about the disjuncture between interior belief and external behaviour that was shared on both sides of the confessional divide and exacerbated by concern about the legitimacy of disguising one's true convictions behind a cloak of compliance to avoid persecution. ${ }^{109}$ Even as they condemned recusancy, the Protestant controversialists who refuted Persons could not but endorse their enemies' denunciation of the duplicity which seemed to underpin nicodemism. ${ }^{110}$ For Catholics and Protestants alike, the pious deceit of the church papist and nicodemite was akin to lying. It was an ideological liability in an environment in which both sought to claim the high moral ground and to present themselves as the true religion. It too laid them open to the charge of deceit and insincerity. The hypocrisy of those who disguised their real beliefs for the sake of an easy life and survival was condemned as a species of 'atheism' itself. Ministers and pastors from both churches denounced it as a variety of unbelief, the unbelief not of those who repudiated God, but of those who failed to defend the faith in the overt and zealous way that became obligatory in

\footnotetext{
${ }^{108}$ Batman, Doome, pp. 408-9, 395 respectively.

${ }^{109}$ In general see Perez Zagorin, Ways of Lying: Dissimulation, Persecution, and Conformity in Early Modern Europe (Cambridge, MA, 1990), esp. chs 7, 10; Miriam Eliav-Feldon, Renaissance Imposters and Proofs of Identity (Basingstoke, 2012), ch. 2. Wider concerns about dissimulation are discussed in Jon R. Snyder, Dissimulation and the Culture of Secrecy in Early Modern Europe (Berkeley, 2009).

${ }^{110}$ Persons discusses dissimulation as his sixth reason: Brief discours, fos $33 \mathrm{v}-37 \mathrm{v}$. For recognition of the principle across the confessional divide, see Walsham, 'Ordeals of Conscience: Casuistry, Conformity and Confessional Identity in Early Modern England', in Harald Braun and Edward Vallance, eds, Contexts of Conscience in the Early Modern World (Palgrave, 2004), pp. 32-48, 191-6.
} 
this age of confessionalisation. ${ }^{111}$ And 'dissemblers' who acted in contravention of their consciences were of great concern to key figures involved in the Orton affair: the author of Richard White's life described the strange mental torments and bodily punishments that afflicted a Catholic gentleman who had been persuaded by 'carnall friends' to renounce his allegiance to the Church of Rome and several chapters of Robert Gwyn's Gwssanaeth y gwŷr newydd were dedicated to recouting the divine judgements that had befallen schismatics in the Llyn peninsula. ${ }^{112}$

Stefania Tutino has charted the process by which, around the same time, both verbal and behavioural dissimulation became a fully developed evangelical strategy, an offensive tool that was regarded as vital to the success of the enterprise to reconvert England. As she has brilliantly demonstrated in Shadows of Doubt, equivocation and mental reservation were themselves a symptom of deep philosophical uncertainties about the capacity of language to express truth. Over time and especially in political circumstances such as those that pertained in the British Isles, these hermeneutical concerns became overshadowed by the ethical implications of such actions. ${ }^{113}$ They fed the perception, articulated by George Abbot in in his Questiones sex of 1589 that Catholics in general and Jesuits in particular were guilty of fraud, imposture and deceit and, in the words of Henry Mason's 1624 tract on the topic, of devising a New art of lying. They tarred the missionary agents of the Church of Rome with the brush of Machiavellianism. ${ }^{114}$

\footnotetext{
${ }^{111}$ For example, Persons, Brief discours, fos 44v-45r. See also Walsham, Church Papists, esp. pp. 41-4, 107-8. On atheism, see George Hoffmann, 'Atheism as a Devotional Category', Republics of Letters: A Journal for the Study of Knowledge, Politics, and the Arts, 1 (2010), pp. 44-55; Leif Dixon, 'William Perkins, "Atheisme”, and the Crises of England's Long Reformation', Journal of British Studies, 50 (2011), 290-812.

${ }^{112}$ Thomas, ed., Welsh Elizabethan Catholic Martyrs, pp. 89, 96; Bowen, ed., Gwssanaeth y Gwŷr Newydd, pp. 40-77.

${ }^{113}$ Stefania Tutino, 'Between Nicodemism and "Honest" Dissimulation: The Society of Jesus in England', Historical Research, 79 (2006), pp. 534-53; and Shadows of Doubt: Language and Truth in Post-Reformation Catholic Culture (Oxford, 2014).

${ }^{114}$ George Abbot, Quaestiones sex, totidem praelectionbius, in schola theologica, Oxoniae, pro forma, habitis, discussae, et disceptatae (Oxford, 1598), esp. p. 4; Henry Mason, The new art of lying covered by Jesuites under the vaile of equivocation (London, 1624). See also Johann P. Sommerville, 'The "New Art of Lying":
} 
The same vocabulary pervades Barnaby Rich's True report of a late practise enterprised by a Papist, which concluded with a prayer that the Lord might deliver Catholics from their 'lying lippes' and 'deceiptfull tongue'. ${ }^{115}$ The sarcastic and offhand tone of his pamphlet should not deceive us. Behind his cheap gibes and scoffing contempt for the "pretie stuffe' and 'trashe' by which the 'foolish credulitie' of simple papists was abused and the kingdom of Antichrist propped up lay a virulent hatred of Catholicism - a hatred which led Rich to excoriate its adherents in Ireland and to advocate a scorched-earth policy for reducing this rebellious race to obedience in his Allarme to England (1578). ${ }^{116}$ Written at the behest of a Chester physician called Richard Joiner, 'sometymes a disciple of the Popes' and a chief companion of Edmund Campion in Oxford, the True report was surely more than a piece of journalistic ephemera and sensational scandal-mongering. It should probably be viewed as a salvo in the polemical campaign provoked by the advent of the Jesuits. ${ }^{117}$ Rich had close links with the Queen's principal secretary and chief spymaster Francis Walsingham (with whom he shared a cousin, Robert Pypho), and to whom he dedicated his book saying that he was bound to him 'by severall good turnes'. ${ }^{118}$ Could Rich have been part of Walsingham's motley crew of spooks? ${ }^{119}$ A soldier whose military career provided cover for his activities as an informer and intelligence gatherer, there are strong reasons for suspecting that Rich's savagely comic tract about Elizabeth Orton was a deadly serious piece of semi-official

Equivocation, Mental Reservation, and Casuistry', in Edmund Leites, ed., Conscience and Casuistry in Early Modern Europe (Cambridge and Paris, 1988), pp. 159-84;

${ }^{115}$ Rich, True Report, sig. E4r.

${ }^{116}$ Rich, True report, sigs D4v, E1r. Barnaby Rich, Allarme to England foreshewing what perilles are procured, where the people liue without regarde of martiall lawe (London, 1578). His other works on Ireland include $A$ short survey of Ireland (London, 1609); A new description of Ireland (London, 1610), reprinted as A new Irish prognostication, or popish callender (London, 1624); The Irish hubbub, or, the English hue and crie (London, 1617). On Rich's career in Ireland, see Terry Clavin and Anthony M. McCormack, 'Barnaby Rich', in James McGuire and James Quinn, eds, Dictionary of Irish Biography (Cambridge, 2009), viii. 477-9; Eugene Flanagan, 'The Anatomy of Jacobean Ireland: Captain Barnaby Rich, Sir John Davies and the Failure of Reform, 1609-22', in Hiram Morgan, ed., Political Ideology in Ireland, 1541-1641 (Dublin, 1999), pp. 158-80.

${ }^{117}$ Rich, True report, sig. A3r.

${ }^{118}$ Ibid., sig. A3r-v. See Maley, 'Rich, Barnaby (1542-1617)'.

119 There is no reference to him, however, in John Cooper, The Queen's Agent: Francis Walsingham at the Court of Elizabeth I (Faber, 2011) or Stephen Alford, The Watchers: A Secret History of the Reign of Elizabeth I (London, 2012). 
propaganda which deployed laughter as a devastating weapon against resurgent Catholicism and the Counter Reformation. In this sense, it too entailed a form of dissimulation. It was a text that disguised its true political intent behind the façade of entertainment.

Significantly, Rich's pamphlet echoes an earlier tract 'disclosing' the 'dissimulation' and 'hyposcrisie' of two young girls, Agnes Briggs and Rachel Pindar, whose claims to have been possessed by the devil had been revealed as fraudulent in 1574 . They confessed to feigning their sickness and to counterfeiting other disturbing symptoms and were made to acknowledge their offences before the archbishop of Canterbury, Matthew Parker, and publicly at Paul's Cross. Published 'cum privilegio', it was designed to rebuff those who 'would delude Gods good people, and the Queenes majesties subjects, with manifest untruth'. ${ }^{120}$ The true report also followed in the footsteps of William Lambarde's account of the maid of Kent affair in his Perambulation of the county published in 1576, which likewise drew upon an unpublished pamphlet by a 'doltish dreamer' to 'decipher' Elizabeth Barton's dissimulation and remind readers of their deliverance from popish 'superstition' and Satanic delusion. ${ }^{121}$ It foreshadowed the rhetorical tactics deployed by in Samuel Harsnet in his scurrilous Declaration of egregious popish impostures (1603) against the puritan and Catholic exorcists John Darrell and William Weston and the young accomplices and anticipated the arguments rehearsed in Abraham Hartwell's English translation of a book about the pretences of the French demoniac Marthe Brossier, published in 1599. ${ }^{122}$ More

\footnotetext{
${ }^{120}$ The disclosing of a late counterfeyted possession by the deuyl in two maydens within the citie of London (London, [1574]). On this case, which occurred in the context of the Vestiarian controversy, see Kathleen Sands, Demon Possession in Elizabethan England (Westport, CT, 2004), ch. 6.

${ }^{121}$ William Lambarde, A perambulation of Kent: Conteining the Description, Hystorie, and Customes of that Shyre (London, 1576), pp. 148-53. Rich's tract also has something in common with Reginald Scot's celebrated book unmasking magic as an art of diabolical and human illusion: The discoverie of witchcraft wherein the lewde dealing of witches and witchmongers is notablie detected (London, 1584).

${ }^{122}$ Samuel Harsnet, A discouery of the fraudulent practises of Iohn Darrel (London, 1599) and A declaration of egregious popish impostures to with-draw the harts of her Maiesties subiects from their allegeance, and from the truth of Christian religion professed in England, vnder the pretence of casting out deuils (London, 1603); Michel Marescot, A true discourse, vpon the matter of Martha Brossier of Romorantin pretended to be possessed by a deuill, trans. Abraham Hartwell (London, 1599). Allegations of fraud were also critical to the exposure of Anne Gunter and in the case of Mary Glover, on which see James Sharpe, The Bewitching of Anne
} 
revealingly still, both its format and tone were mimicked by Richard Baddley in The boy of Bilson (1622), an account of the Staffordshire youth William Perry, who faked his possession by the devil to avoid going to school, colluded with certain priests in his pretended exorcism, and like Elizabeth Orton, was eventually induced to confess his errors before the local bishop. This too faithfully reproduced an unpublished Catholic pamphlet about the affair, which Baddeley thought it his duty to make 'iuris publici' to describe 'the admirable guile and cunning' of the dissembling child, to uncover how 'the Popish Priests ... take delight, and blush not, daily to forge and coyned most monstrous untruths' and to warn against the 'enveagling projects' of 'the rarest Mountebanks of these times'. ${ }^{123}$ The themes of theatricality, deceit and ventriloquism that pervade these books were an embedded in antiCatholic discourse from the beginning they left a lasting legacy. ${ }^{124}$ Protestants persisted in repeating the commonplace that the Jesuits specialised in forging 'mendacious prodigies', 'Ignatian fables', and 'loud ringing lyes'. The 'juggling shifts' and 'dog-tricks' of priests who persuaded two other young girls to affect 'ecstatical raptures' in which they were inhabited by the spirit of the Virgin Mary, St Michael the Archangel, St John the Baptist, and a pair of Tyburn martyrs in 1617 was just one of the false miracles cited by John Gee in his The Foot out of the Snare (1624). ${ }^{125}$ Such texts deployed comedy and humour as an antidote to the poison of a religion that it was conventional to condemn as one huge illusion.

Gunter: A Horrible and True Story of Football, Witchcraft, Murder and the King of England (London, 1999) and Michael MacDonald, ed., Witchcraft and Hysteria in Elizabethan London: Edward Jorden and the Mary Glover Case (London, 1991).

${ }^{123} \mathrm{R}$ [ichard] B[addeley], The boy of Bilson: or, a true discovery of the late notorious impostures of certaine Romish priests in their pretended exorcisme, or explusion of the divell out of a young boy, named William Perry (London, 1622), title-page, sigs A3r-4r, and passim.

${ }^{124}$ See Rob Iliffe, 'Lying Wonders and Juggling Tricks: Religion, Nature, and Imposture in Early Modern England', in James E. Force and David S. Katz, eds, Everything Connects: In Conference with Richard H. Popkin (Leiden, 1999), pp. 185-209.

${ }^{125}$ Richard Sheldon, A survey of the miracles of the church of Rome, proving them to be antichristian (London, 1616), quotations at pp. 60 and 23; John Gee, The foot out of the snare with a detection of sundry late practices and impostures of the priests and Iesuites in England (London, 1624); ed. T. H. B. M. Harmsen (Nijmegen, 1992), quotations at pp. 126, 131, and see ch. 7 passim. 
By the mid seventeenth century a tendency to utilise the rhetoric of imposture to impugn Protestant enthusiasts as well as Romanist ones had become well established, with the consequence that Quakers and other radical sects were commonly conflated with papists. ${ }^{126}$ Levelled in multiple directions against many targets, allegations of deception and misrepresentation became the very stuff of partisan politics after the Restoration, further contributing to the swirling instability of post-Civil war and revolutionary Britain. ${ }^{127}$ The result of the promiscuous deployment of the category of fraud as an ideological and cultural weapon was to destabilise and relativise it in a manner that fatally blurred the boundaries between truth and falsehood. ${ }^{128}$ And if Elizabeth Barton, the holy maid of Kent, continued to be remembered as a notorious imposter so too did Elizabeth Orton, the holy maid of Wales. Along with William Perry, the Boy of Bilson, the counterfeited trances of both women appeared as paradigms of popish deceit in Francis Hutchinson's Historical Essay concerning Witchcraft of 1718 - a text that sought to expose a long list of cheats as part of a wider campaign to underline the futility and irrationality of burning witches, whose confessions were recognised as often manufactured themselves, and to confute 'vulgar errors' concerning ‘imaginary communications’ with good and bad spirits. By contrast with previous commentators, Hutchinson placed much less emphasis on the priests who had managed their 'strange Trances' and 'mighty Agonies' and laid most of the fault at the feet of the young women themselves. ${ }^{129}$ It is equally revealing that the effect of the act of 1735 was not to abolish the crime of witchcraft but to redefine it: as an act not of diabolically inspired

\footnotetext{
${ }^{126}$ See S. A. Kent, 'The "Papist” Charges against the Interregnum Quakers', Journal of Religious History, 12 (1982), pp. 180-90.

${ }^{127}$ See Mark Knights, Representation and Misrepresentation in Later Stuart Britain: Partisanship and Political Culture (Oxford, 2005) and The Devil in Disguise: Deception, Delusion, and Fanaticism in the Early English Enlightenment (Oxford, 2011), esp. pp.4-7.

${ }^{128}$ Cf. Keitt, Inventing the Sacred, p. 206, 244, and passim.

${ }^{129}$ Francis Hutchinson, An historical essay concerning witchcraft (London, 1718), pp. 301-4 (Boy of Bilson), 24 (Elizabeth Barton), 30 (Elizabeth Orton), and see dedication pp. v-xiv. The case of William Perry was also invoked in The second part of the boy of Bilson: or, a true and particular relation of the impostor Susanna Fowles (London, 1698), pp. 1-9. Here it is said that the Catholic priests actually coached him in the part of the possessed adolescent, shifting the emphasis of the story from credulity to fraud. See Underwood, Childhood, Youth and Religious Dissent, p. 165.
} 
malevolence but of pretence and fraudulence. ${ }^{130}$ Too often deployed as a self-evident concept, the epistemological status of the latter was changing against a backdrop in which magic itself seemed increasingly capricious and implausible. Slowly, it lost its earlier connotations of diabolical guile and became associated more exclusively with human corruption. ${ }^{131}$ Once a label used to denote people who led others to believe in lies and who were seduced by the arch-deceiver Satan, the word imposter too was likewise gradually migrating towards its primary meaning of an individual who engages in impersonation. ${ }^{132}$

Simultaneously, the rhetoric of religious imposture deployed against Elizabeth Orton was beginning to be turned against Christianity itself. It was a central thread of the radical Enlightenment critique of institutionalised religion, which in an echo of the Reformation, contributed to eroding its credibility. Implicated in the battle between believers and sceptics, it helped to sow the seeds of deism, doubt and disbelief. ${ }^{133}$ Interestingly, this occurred at around the same time as fears about the other species of religious dissimulation discussed in this essay started to wane: as the belief that sincere profession of error was preferable to hypocritical profession of the truth gained ground and paved the way for toleration. While Protestant dissenters were no longer obliged to conform outwardly and church papistry largely disappeared for other reasons, ironically it remained necessary for atheists to camouflage their opinions in a society that still conceived of itself as a Christian community. Concern was shifting from people who adhered to the wrong faith to those who professed the right one with insufficient inward conviction. Dissimulating ceased to be sanctioned as a

\footnotetext{
1309 Geo. II c. 5. On this see Owen Davies, 'Decriminalising the Witch: The Origin of and Response to the 1736 Witchcraft Act', in John Newton and Jo Bath, eds, Witchcraft and the Act of 1604 (Leiden, 2008), pp. 207-32.

${ }^{131}$ I am very grateful to Michael Hunter for sharing with me an unpublished paper on 'The Role of Fraud in the Decline of Magic'.

132 Silvia Berti, 'Unmasking the Truth: The Theme of Imposture in Early Modern European Culture, 16601730', in Force and Katz, eds, Everything Connects, pp. 21-36. See also OED, s.v. 'imposture'.

${ }^{133}$ Lancelot Addison and Humphrey Prideaux applied it to the founder of Islam, Mahomet, and freethinkers extended it to the originators of the other monotheistic faiths, Moses and Christ. These 'three imposters' became a standard trope in early Enlightenment discourse: Berti, 'Unmasking the Truth'. See Eliav-Feldon, Renaissance Impostors, p. 14, 67-8.
} 
means of protecting one's inner vulnerability, and became more exclusively associated with malicious and sinister trickery. ${ }^{134}$

\section{CONCLUSION}

The story of Elizabeth Orton is far more than an intriguing footnote. It must be seen as a reflection and catalyst of the dangerous political instabilities created by the Reformation in Britain. It opens a window onto a moment in which the Elizabethan regime believed that a Catholic restoration effected by a combination of force and persuasion was highly likely and saw north Wales as an obvious entry point for foreign invaders. It shows that rural Flintshire and the Marches were by no means peripheral to the European Counter Reformation; on the contrary they were key locations in an internationally coordinated campaign to reclaim Britain to allegiance to Rome. ${ }^{135}$ The events in Overton had profound repercussions in Chester and Westminster. Scribal publication, vernacular prophecy, bardic culture, and itinerant missionaries allied to disseminate accounts of visions and martyrdom that provided a focal point for spiritual renewal and for a self-consciously Welsh religious militancy that the Protestant regime could not afford to ignore. Simultaneously they served to link her experiences with a late medieval tradition of female sanctity that remained resilient in this bilingual frontier region and with new currents of affective and mystical piety that were becoming as controversial as they were fashionable across Catholic Europe.

If Elizabeth Orton has largely been forgotten, this is partly because of the low esteem in which the printed output of Barnaby Rich has been held by literary critics. It is also a

\footnotetext{
${ }^{134}$ Berti, 'Unmasking the Truth', p. 25.

135 This reinforces the neglected work of Martin Cleary, 'The Catholic Resistance in Wales 1568-1678', New Blackfriars, 38 (1957), pp. 111-25; and the more recent studies of Thomas M. McCoog, 'The Society of Jesus in Wales; The Welsh in the Society of Jesus, 1561-1625', Journal of Welsh Religious History, 5 (1997), pp. 1-27 and Hannah Thomas, 'Missioners on the Margins? The Territorial Headquarters of the Welsh Jesuit College of St France Xavier at the Cwm, c. 1600-1679', Recusant History, 32 (2014), pp. 173-93.
} 
reflection of the tendency of an earlier generation of historians to dismiss stories involving optical apparitions and audible voices emanating from heaven as irrational and to regard them as embarrassments - symptoms of a form of religious 'enthusiasm' that was progressively marginalised from mainstream piety. Echoing sixteenth- and seventeenth-century rhetoric, they were inclined to categorise female seers and visionaries as hysterical women who were the unwitting victims of male lay and clerical manipulation. Our lingering instinct to interpret prophecies and revelations in this way perpetuates the polarities and reproduces the prejudices inherent in sixteenth-century polemic. It is a measure of how far "narratives of suspicion' and condescension still underpin the history of religion. ${ }^{136}$

As we have seen, in the early modern era the whole question of the possibility of seeing and hearing supernatural beings was problematized by the profound theological conflicts between Catholics and Protestants, which converged with philosophical debates that were likewise throwing settled assumptions about the status of optical and sensory experiences into disarray. One of the consequences of what Clark has called the 'reformation of the eyes' was to surround sightings and other sensory perceptions of God, the saints and the afterlife with hermeneutical unease and to eclipse their ongoing role in the devotional and spiritual lives of early modern people. ${ }^{137}$ Orton's visions are an index of philosophical and theological shifts that at once intensified and complicated the possibility of encountering the divine.

Finally, this incident must also be seen as a chapter in the history of imposture and fraud. It demonstrates how these concepts became implicated in the religious politics of this era. These conflicts had the effect of engendering an outbreak of pious deceit and

\footnotetext{
${ }^{136}$ Leigh Eric Schmidt. Hearing Things: Religion, Illusion and the American Enlightenment (Cambridge, MA, 2000), p. 33 and passim. See also Alec Ryrie, Being Protestant in Reformation Britain (Oxford, 2013), pp. 1314.

${ }^{137}$ Stuart Clark, 'The Reformation of the Eyes: Apparitions and Optics in Sixteenth- and Seventeenth-Century Europe', Journal of Religious History, 27 (2003), 143-60.
} 
dissimulation, of creating a class of individuals who hid their religious beliefs behind a cloak of conformity to avoid the penalties of the law. They fostered a widespread fear of hypocrisy: of a disjuncture between how people appeared and who they really were. In mid Elizabethan England and Wales these two sets of concerns became closely entangled. They assisted in forging a link between religious deceit and private insincerity that had significant implications. They provided a potent rhetoric and language by which occult and mystical experiences could be discredited and may, in a small way, have helped to shape our own post-Enlightenment cynicism about the reality of such phenomena.

The foregoing discussion has deliberately evaded the treacherous question of whether or not Elizabeth Orton was really a fraud and analysed her ecstasies as a cultural fact, as well as a social construct. ${ }^{138}$ Her own voice is the hardest to disentangle from the source material and sometimes it is inaudible. Refracted through the prism of the Catholic and Protestant writers who constructed competing images of the young seer and made her a mouthpiece for their own theological and political agendas, she is the most elusive figure in the whole drama that unfolded around her. Just one tantalising trace of this brave young woman can be found in the Chester ecclesiastical records, a note of her appearance before the diocesan chancellor in April 1589, some seven years after her humiliating public confession in the cathedral. This reveals that she had been a recusant and excommunicate for a prolonged period - her absence from her parish church was motivated by the 'lewde report \& dyslyke shee' had for the services said there. But now she was willing to conform and declared that she would 'bee dutifull to her Ma[jes]ties proceadinges and will nott hearafter bee soe obstinite'. ${ }^{139}$ This suggests that her second recantation was itself an act of equivocation. In the wake of the

\footnotetext{
${ }^{138}$ Cf. Tobias B. Hug's attempt to draw a distinction between prophets who deliberately assumed a false identity and those who sincerely believed that they had special insight but were rejected by their peers in Impostures in Early Modern England: Representations and Perceptions of Fraudulent Identities (Manchester, 2009), p. 10 and ch. 4.

${ }^{139}$ Chester, Cheshire Archive and Local Studies Service, EDV 1/8a \&b (Correction Books 1589-90), fo. 9r.
} 
Spanish Armada scare and the sharp crackdown on Catholic nonconformity that followed, Elizabeth Orton seems once again to have dissembled her faith in response to pressure exerted by the Protestant regime. This should be seen less as evidence of human vulnerability than as an act of resistance and agency itself. Although we cannot open a window into her soul, it seems likely that she sought safety and refuge by divorcing her exterior conduct from her inner conscience and by concealing her real religious identity. In this sense at least, she may indeed have been a kind of imposter. 